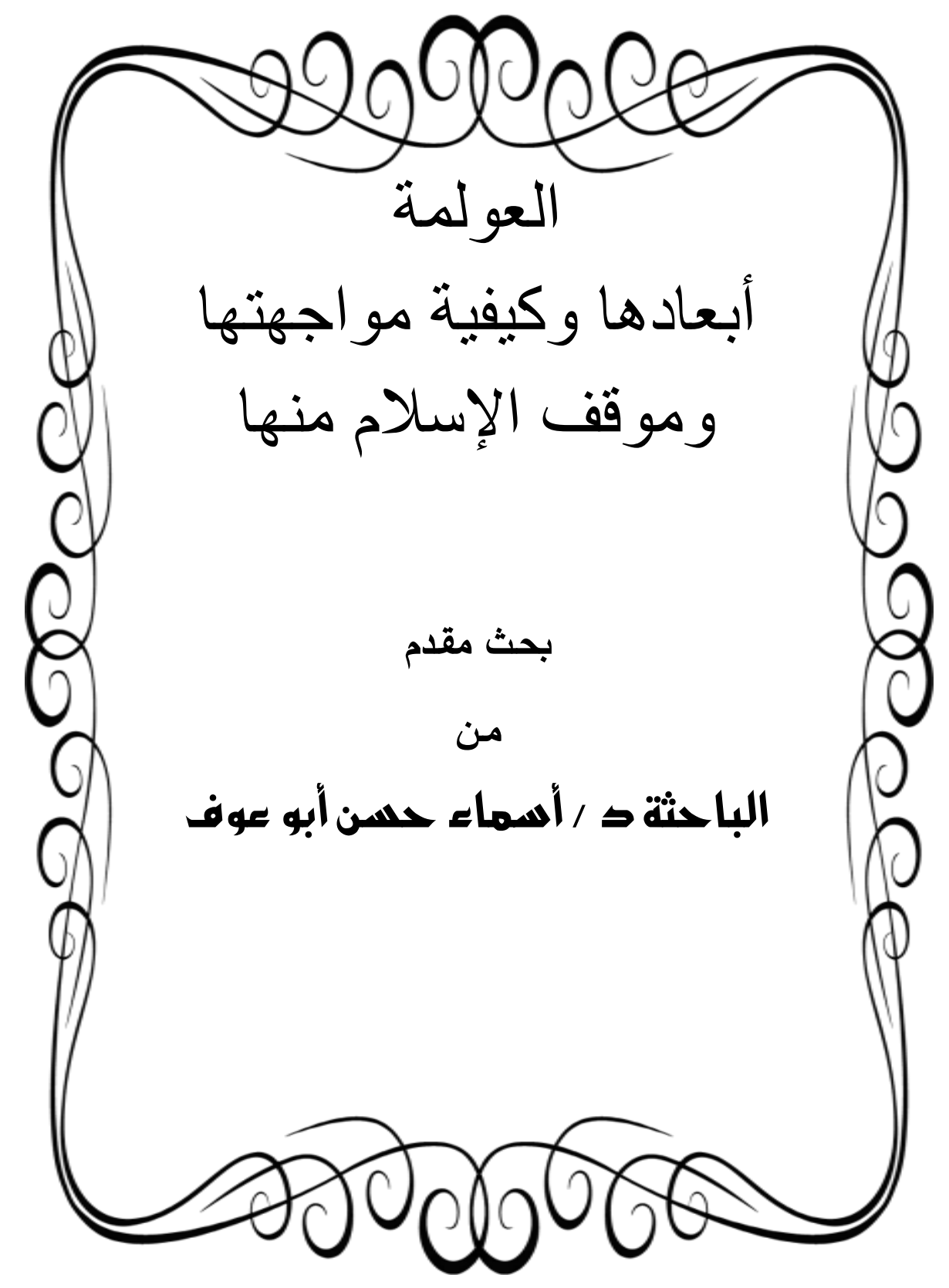


العولمة أبعادها وكيفية مواجهتها وموقف الإسلام منها

1076

$=$

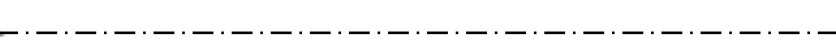


الحمد الله رب العالمين ، والصـلاة والسـلام على سيد المرسلين، سيدنا محمد ئس وعلى آله وصحبه وسلم تسليمًا كثيرًا إلى يوم الدين

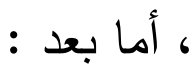

مـن الظـواهر ـ أو التيـارات إن صـح التعبيـر ـ الحديثـة التـي

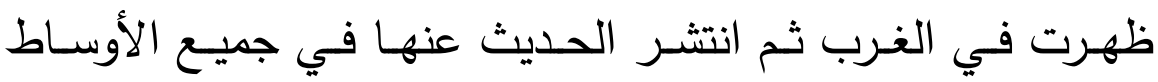

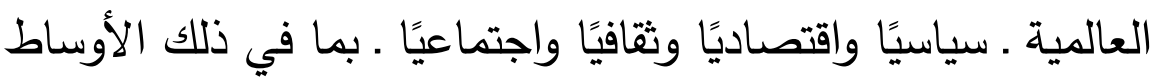
العربية والإسـامية ، تيار العولمـة ـ أو ظـاهرة العولمـة ـ التي هي

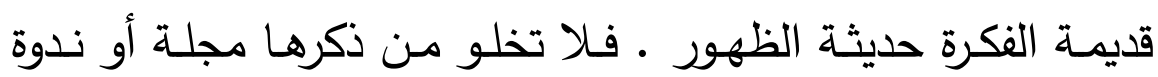

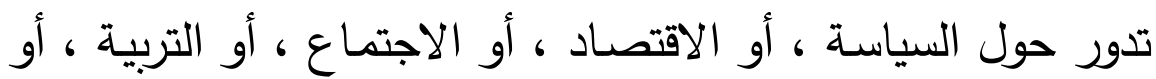

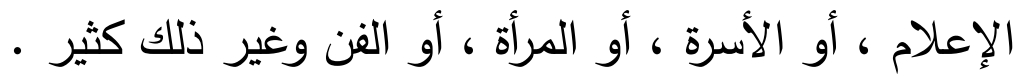
وكان تيار العولمة الذي تفجر في الآونة الأخيرة ، أثد صدمة لإيقاظ العقل واستتهاض الفكر ، وتحمل المسئولية لمواجهة مخاطر

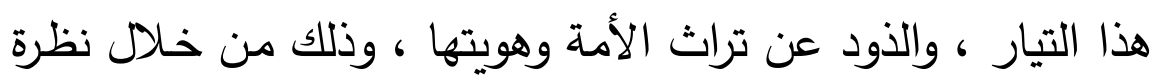
واقعية للظاهرة .. . بعلاهـا وآثارها المتوقعة وتقويم هذه الظاهرة ، وتحديد موقف الإسلام منها ومواجهاتها .

وقد سبق تيار العولمة ، تيار الحداثة وثبت فشله ، واضمحلاله ، ثم أطلقوا مصطلحًا آخر عليه ـ ما بعد الحداثة ـ ولحق به الفشل 
كما سيلحق بالعولمة ـ بمشيئة الله ـ من انطفاء لمعانه وانهياره.

وسيظل الصراع بين الحق والباطل قائمًا ما بقيت البشرية ، وسيظل الحـق مسـموع الكلمـة مرفـوع اللـواء مهمــا كانــ دعـاوى الباطلـل

وسطوته(1) (1) (1)

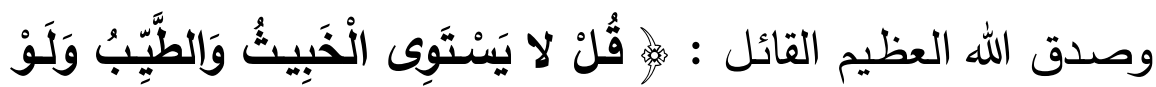

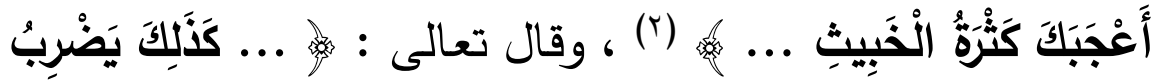

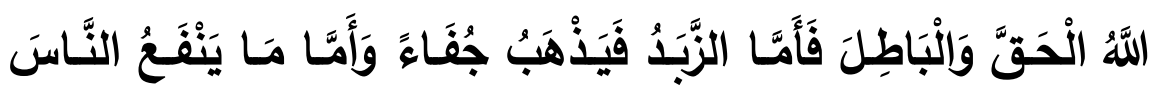

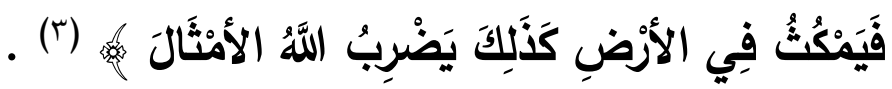
فالعولمـة في نظر الكثيرين من ذوي الرؤيسة الإسـامية الصـائبة ، ما هي إلا محاولة لسحق الهويـة الإسـلامية ، وطمس معالمها ، ومحو الشخصية . ولذلك وجدت في نفسى الرغبـة في البحث ، في هذا التيار ، الذي أصبح واقعًا يفرض نفسه على العالم ؛ من خلال المنظمات والهيئات الدولية .

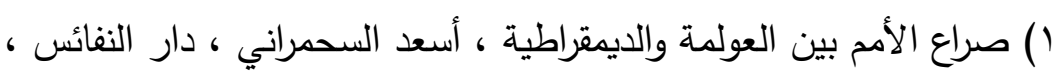

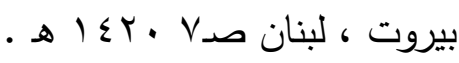

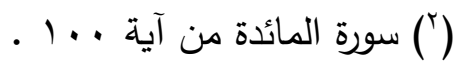

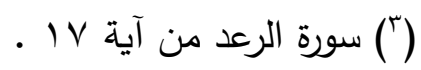


حولية كلية الدراسات الإسلامية والعربية بنين بالقاهرة العدد (r r)

وبعد الاستعانة بالله تعالى ، قسمت البحث إلى مقدمة ومبحثين

وخاتمة ومصادر البحث ثم الفهرس •

ذكر في المقدمة : أهمية الموضوع ، وسبب اختياري له .

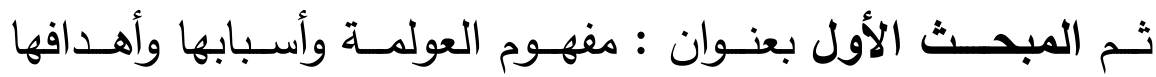

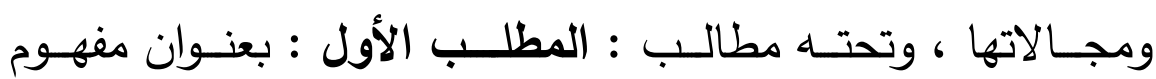

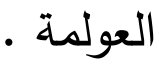

والمطلب الثاني : بعنوان أسباب نثأة العولمة . أما المطلب الثالث : أهداف العولمة . والمطلب الرابع : مجالات العولمة ـ أبعادها ـ . وتتاولـت فـي المبحـث الثـاني : الآثـار السـيئة للعولمــة وكيفيـة مواجهتها ـ وأيضًا تحته مطالب : المطلب الأول : الآثار السيئة للعولمة . المطلب الثاني : العولمة في إطار الإسلام . المطلب الثالث : مواجهة الإسلام للعولمة الغربية . ثم الخاتمة : ذكرت فيها أهم النتائج التي توصل إليها البحث وأهم

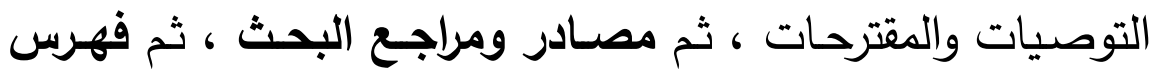

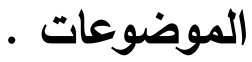


العولمة أبعادها وكيفية مواجهتها وموقف الإسلام منها

1080

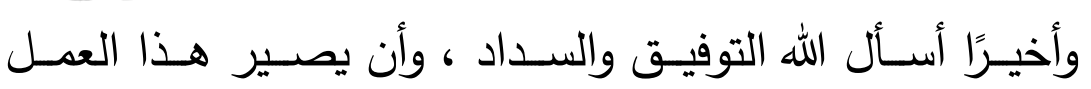

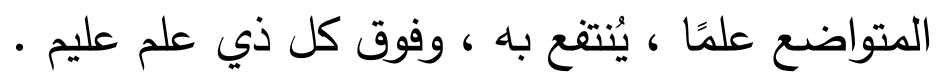

الباحثة - - م 


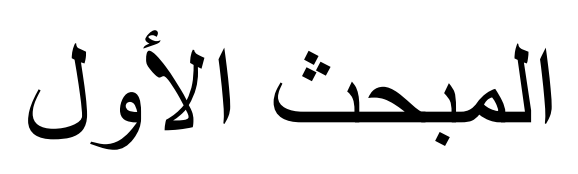

مفهوم العولمة و أسبابها

$$
\text { و أهدافها ومجالاتها }
$$

$$
\text { وفيه هطالبب : }
$$

المطلب الأول : مفهوم العولمة .

المطلب الثاني : أسباب نثأة العولمة .

$$
\text { المطلب الثالث : أهداف العولمة . }
$$

المطلب الرابع: مجالات العولمة ـ أبعادها .. 


\section{العولمة أبعادها وكيفية مواجهتها وموقف الإسلام منها}

\section{الإطباب الأول}

\section{مفهوم العوملة}

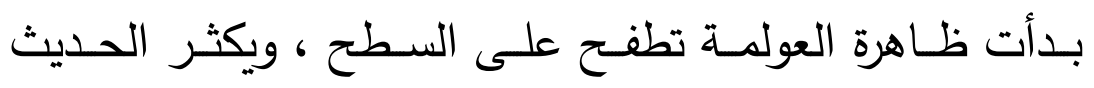

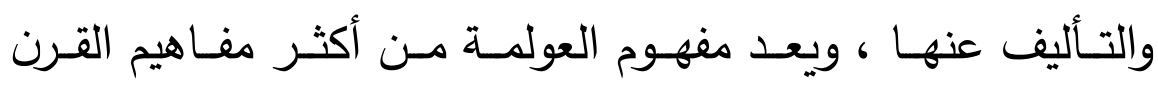

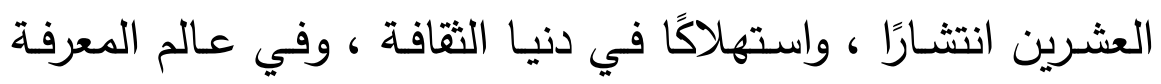
والعلوم • وبالتحديـــــي الثمانينـات مـن أواخـر القـرن العشـرين

$$
\text { الميلادي (') }
$$

بدأ هذا الدصطلح ـ العولمــة ـ المـادة المفضـلة لدى وسـائل الإعلام المختلفة على تباين اتجاهتها واختلاف أهدافها .

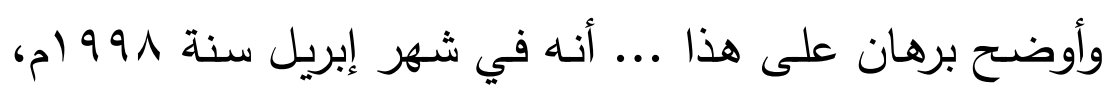
عُقد مؤتمر بالقاهرة واستمرت أعماله لمدة خمسة أيام عن العولمة ، وقضايا الهوية الثقافية ... وعلى الرغم من البحوث والمداخلات الكثيرة إلا أن المؤتمر انتهى كما جاء في بعض التحقيقات عنهـ ـ وكل واحد يفهم العولمـة بغير ما يفهمها الآخر ، وكل وقف عند فهمه ، وقال أحد المعلقين

(') صراع الأمم بين العولمة والديمراطية ، أسعد السحمراني صد ، دار النفائس .

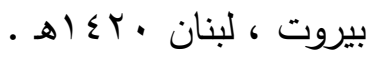


في المؤتمر : لقد خرجنا من المؤتمر بأسئلة أكثر مدا دخلنا فيه ، وبحيرة أكثر عن العولمة (') .

ومصــطلح "العولمــة" هــو ترجمـــة لكلمـة Globalization الإنجليزية ، التي ظهرت أول الأمر في الولايات المتحدة الأمريكية ، وهي تفيد معنى تعميم الثيء وتوسيع دائرته ليشمل الكل (r) . والعولمـة كفكـرة ليســت جديـدة تماثَّا ، لكـن سـبقها كثيـر مـن الأفكار والنظريات التي تتشابه معها إلى حد كبير • فالعالميــة Internationalism كفكـرة أقـدم مـن العولمــة ، " فالعالميـة تدعو لانفتـاح الدول بعضهها على بعض في علاقات اقتصـادية وسياسـية ، وتبـادل ثقـافي إيجـابي مـع احتفـاظ كل دول العـالم بحـدودها القوميـة وخصوصسياتها الثقافيـة المتميـزة ، وأيضًــا سـيطرتها على كامـل أفرادهـا ، ووحدتها الاقتصـادية والسياسـية ، ومن خلال العالمية فإن كل الدول تستفيد وتكسب " (r) .

(') العولمة الغربية والصحوة الإسـلامية ( الموقف الرشيد ) ، عبد الرحمن بن زيد

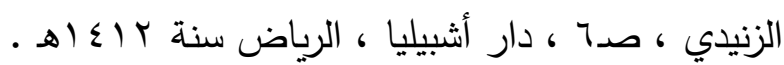
(†) قضايا في الفكر المعاصر : العولمة . ـصراع الحضـارات محمد عايد الجابري

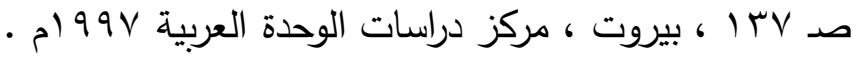

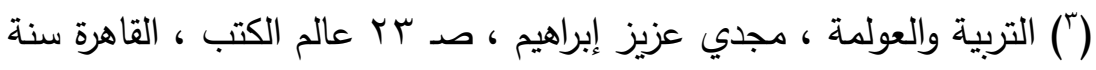


فالعالميـة حـوار متبـادل حيث تطـرح أفكارًا إنسـانية قد تقبـل

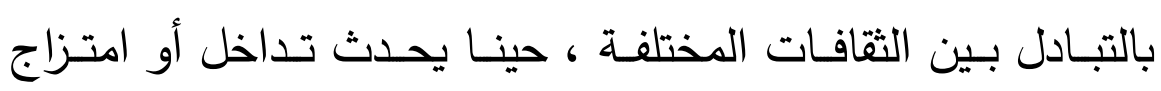
بينها، أمسا العولمسة فهى سيطرة بين الطـرف الأقوى ، في أمور

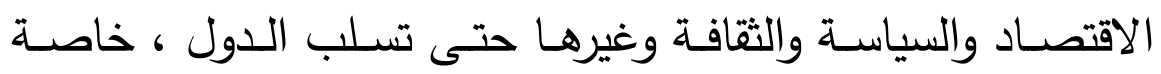

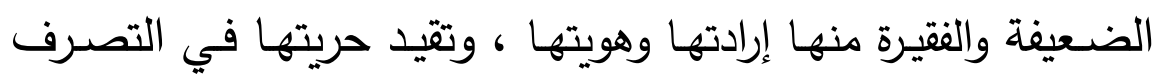

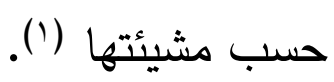

وحاول الكثيرون وضع مفهوم محدد ـ للعولمة ـ باعتبارها ظاهرة

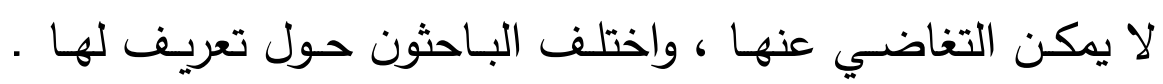

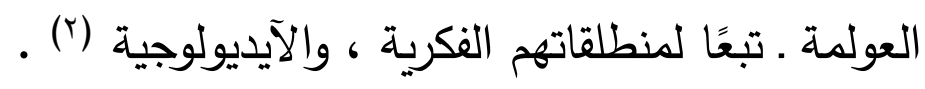
وبالتتبع وجدت تعريفات كثيرة ... أذكر منها :

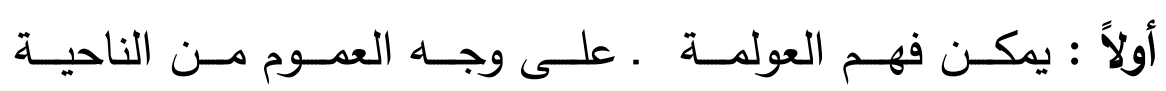

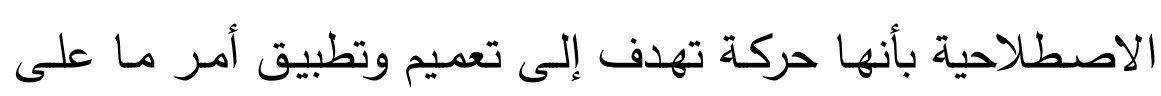

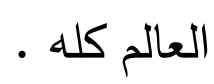

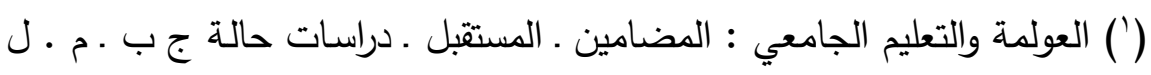

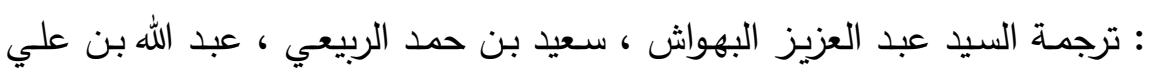

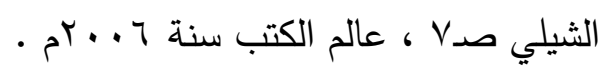

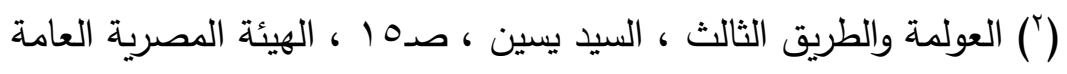

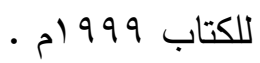


حولية كلية الدراسات الإسلامية والعربية بنين بالقاهرة العدد (r)

فمثلاً : العولمة الاقتصادية : هى جعل الاقتصـاد في جميع أنحاء العالم يتبع النظام نفسه ، ويطبق الأسـاليب ذاتها ، وذلك يتمثل في قيام منظمة التجارة العالمية ، التي قامت لكي تحرس وتراقب مبدأ حرية التجارة والمعاملات الاقتصادية .

أما العولمة السياسية : تتمثل في الديمقراطية والتعددية السياسية ، وحقوق الإنسـان ، والعولمـة الاتصـالية : تبـدو في أن العـالم كله أصبح متصلاً بفضل الثورة الاتصالية الكبرى ، وفي مقدمتها شبكة

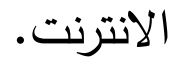

أمسا العولمـة الثقافية : تتمثل في محاولة صياغة ثقافية كونية تقوم على أسـاس نسق عالمي من القيم ، وتوظيف التقدم العلمي التقني المعاصـر لتحقيـق الأمسن والســلام العـالميين ، والسـعي لتحقيـق الرفاهيـة لجميع دول العـالم ، وهي بذلك تصطدم مـع الخصوصية الثقافية للمجتمعات المتعددة ، وهنا صلب مشكلة العولمة ( ) . ثانيًا : ومن مفاهيم العولمة أيضًا تعني : المجتمع الإنساني الواحد، وصـيرورة العـالم واحـدًا علـى الـنمط الغربـي سياسـة واقتصــاديًا

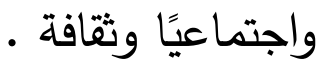

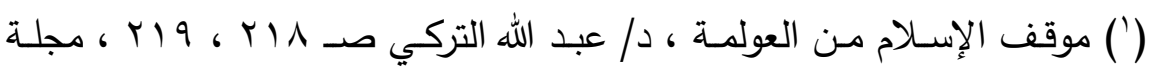

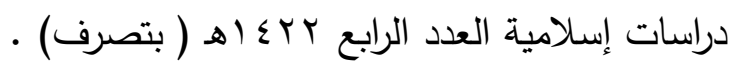


ثالثًّا : اختراق ثقافـات الأمـم الضـعيفة واحتلالهـا مـن قبـل ثقافـات

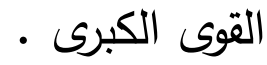

رابعًا : غزو ثقافي واقتصادي تحت غطاء قانوني من المعاهدات والاتفاقات ، عبر انفتاح إعلامي وفضائي . ثورة الاتصالات . خامسًــا : تدفقات وموجـات مـن الغـرب تخترق الحدود السياسـية والوطنيـة للدول ـ هذا مـا حصل هذه الآونـة الأخيرة مـع السـودية

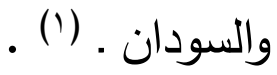

هذه بإيجاز أوضـح مفـاهيم لمصطلح العولمـة مـن حيث حقيقته ، وما يهدف إليه .

إذن نخلص إلى القول : إن العولمـة باختصسار شديد هي أمركة العالم بمعنى أن الولايات المتحدة الأمريكية ، هي القطب الأوحد والقوة الكبرى في العالم ، والتي برزت بعد انهيار الاتحاد السوفيتي وانتصرت في حرب الخليج الثانية ، وهي القوة الاقتصـادية الكبرى ؛ ولهـذا فهـي تفـرض ثقافاتهـا وسياسـتها وأنظمتهــا الاقتصــادية والاجتماعية على العالم كله .

ويذهب البعض إلى أنها (العولمـة) صههينة العالم ؛ لأن الصهاينة (اليهود) لهم التأثير الأكبر على القيادة الأمريكية . وعلى هذا ... (') العولمة الغربية .. نقلاً عن "ملف العولمة" مجلة المعرفة .. محرم وصفر سنة

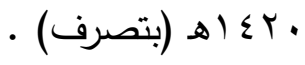


فهي تعني (العولمـة) الهيمنـة والسيطرة من خـلال القوة العظمى... حتـى أصــبح شـائعًا لـدى الجميــح الآن ... أن العولمــة تعنـي

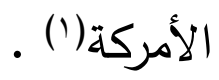

(') العولمة الثقافية وأثرها على الهوية ، خالد بن عبد الله القاسم ، بحث مقدم إلى الى

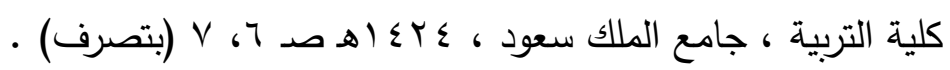




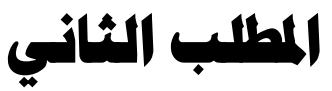

\section{أسباب نشأة العمهلة}

كل كاتب عربـي وهـو يكتب عـن العولمـة يتذكر الاسـتعمار

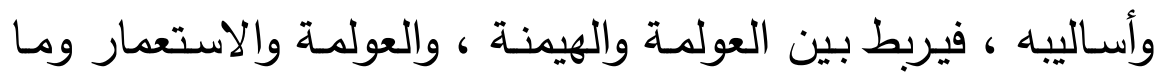

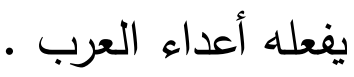

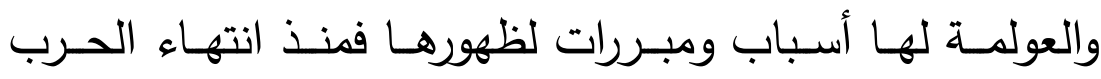
البـاردة وانهيار سور برلين إلى يومنـا هذا مرت العولمـة بتجارب

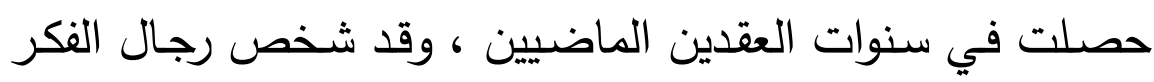
والسياسة ذلك الواقع ، وذكروا أسباب ظهور العولمة ومنها : ا ـ سقوط الاتحاد السوفيتي السابق ، الذي كان يقوم على الفكر

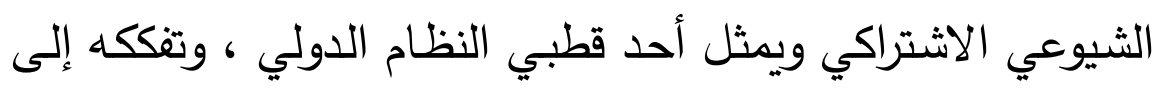
دويلات ، ولعل هذا السبب من أهم الأسباب لنشأة ظهور العولمة .

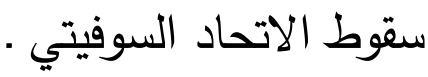

r ـ ـ وبعد سقوط الاتحاد السوفيتي تكون نهايـة الصـراع والمواجهـة بين قطبي النظام الدولي وهي الفكر الثيوعي الاشتراكي الذي كان

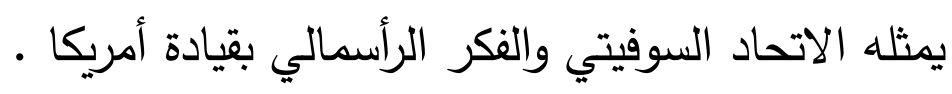

وبذلك توقفت الحرب الباردة بين الحلفين : الأطلسى الأمريكي ، ووارسو السوفيتي ، والتي استمرت أربعة عقود من الزمان ـ 
بم ـ أيضًا مـنـ أسـباب ظهـور العولمــة ، انتصـار الحلفــاء بقيـادة الولايات المتحدة الأمريكية في حرب الخليج الثانية سنة الو99 ام ، وذلك الانتصار ساعد أمريكا على إعلان ما يسمى بالنظام العالمي • الجديد (العولمة) - (المة)

ع. ـ هيمنة النظام الأمريكي على العالم ، تحت ما يسمى بالأحادية • القطبية للعالم

ه ـ امتلاكك الولايات المتحدة الأمريكية لمناطق نفوذ في العالم ، أو الإمسـاك بقرارها ، كحالة دولـة العدو الإسـرائيلي ، أو كحالـة تركيا الخاضـعة للقرار الأطلسـي ، أو بريطانيـا التي تعتبر أكبر حليف استراتيجي لأمريكا في أوربا . 7 ـ الثورة المعلوماتيـة الهائلـة في الاتصـالات وتقنيـة المعلومـات ، والكمبيوتر ، والانترنت والتي زادت في تقارب العالم (') . V ـ أيضًا مدـا أدى إلىى ظهور العولمـة : ظهور منظمـة التجـارة العالميـة سنة 990 (م ، ومقرهـا جنيف ، والتي تهدف إلى تحريـر التجارة من كل القيود الجمركية ، وجعل العالم سوق حرة مشتركة ، وتلافي عيوب اتفاقية الجات ، ومنها عدم شمول تجارة الخدمات وحقوق الملكيـة الفكريـة ، وعـدم وجـود آليـة دوليـة لحل النزاعـات التجاريـة العالميـة ، وعلى هـذا الأســاس ظهـرت منظمــة التجـارة (') العولمة الثقافية وأثرها على الهوية ، خالد القاسم صد ؛ ، مرجع سابق • 
العالميـة لتفتح أبواب الأسواق العالميـة على مصـراعيها أمـام السلع والبضائع الأمريكية لا سيما أسواق اليابان والصين العاب العابه ^ ـ تقارب العالم بعد تحوله إلى قريـة كونية بحكم ثورة الاتصالات

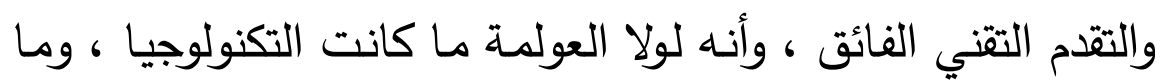
أحدثته من تقدم علمي. 9 ـ ظهور الشركات متعددة الجنسيات (العابرة للقارات) . . 1 ـ ولعل من أهم أسباب ظهور العولمة : أنها نشأت كردة فعل أو تحجيم أو مواجهة للصحوة الإسلامية التي ظهرت في السبعينات والثمانينات من القرن العشرين الميلادي ، مرده

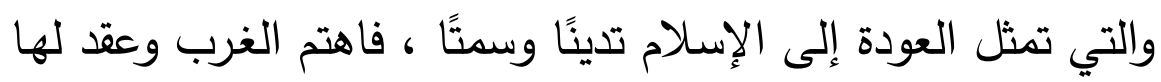

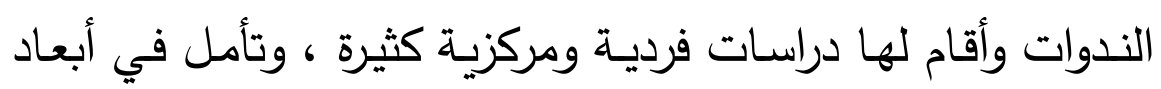

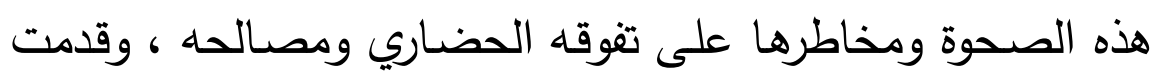

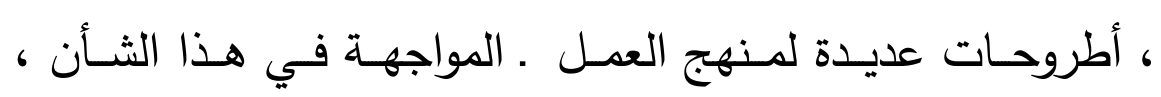

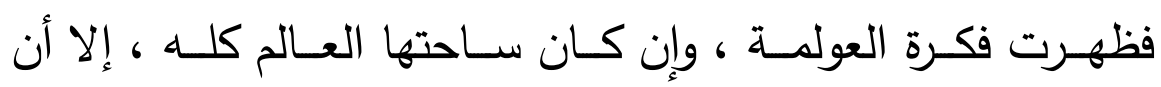

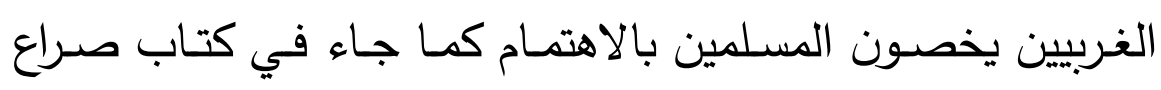

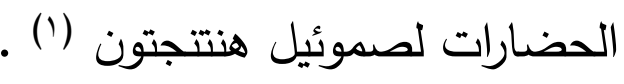
هذه هي أهم الأسباب التي أدت إلى نشأة وظهور العولمة .

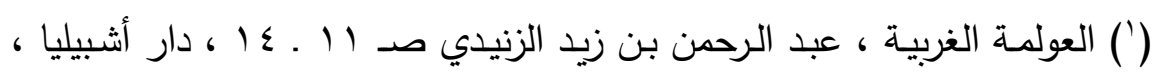
الرياض الب آهـ الهـ 


\section{الإhب الثالث}

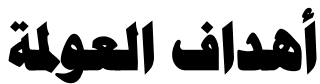

غالبًا أهداف أي موضوع يكون لـه هدف ظـاهر وهدف باطن .

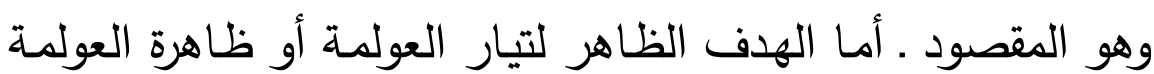
؛ هـو خدمـة البشـرية ، وتوحيد مصـيرها بإزالـة الحـواجز بينهـا ، وإشـاعة القيم الإنسانية في عالمها ، والحفاظ على حريـة الإنسـان

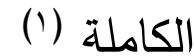

أمـا الهـدف البـاطن ـوهو المقصـود العمـل بـه ــ هو أن الولايـات

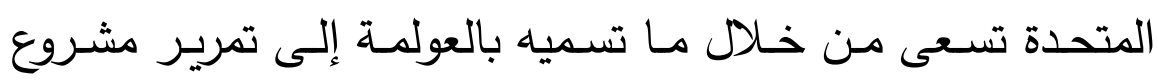

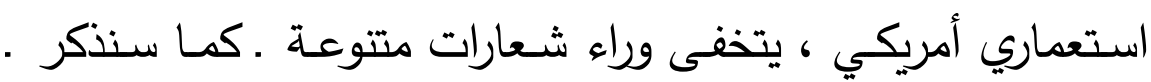
بحكم سيطرتها السياسية والاقتصادية وقبضتها على السوق العالمية مما يجعلها أن تضع ما يتفق مع مصلحتها من قواعد وشروط . ومن أهداف العولمة ما يلي : 1 ـ إحكام سيطرة الولايات المتحدة الأمريكية على اقتصاديات العالم بشكل عام ، وعلى اقتصاديات العالم الإسلامي بشكل خاص . 
r ـ العمـل الجـاد لتثبيـت الأنظمـة الثلاثـة التـي هـي الأسـس في

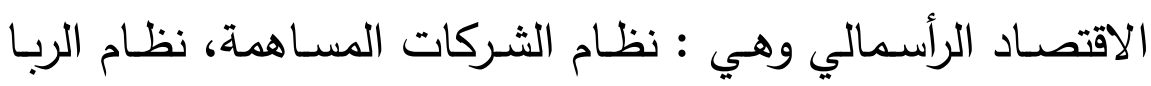
المصرفي ، نظام النقد الورقي الإلزامي. r ـ إيهام العالم ـ من خـلا الحمـلات الإعلاميـة المركزة والإعـلام

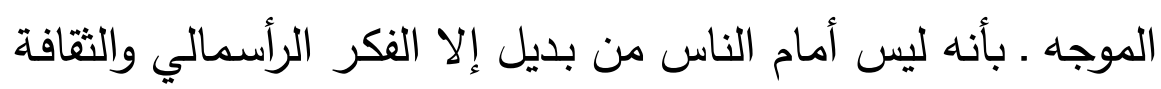
الغربية .

ع ـ القضاء على الأيدولوجيات والثقافات والحضـارات التي لا تدين

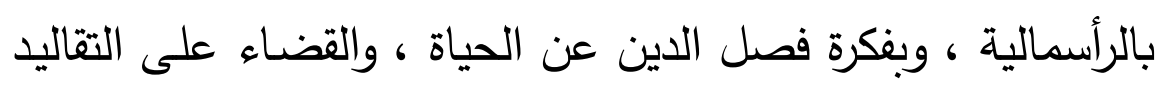

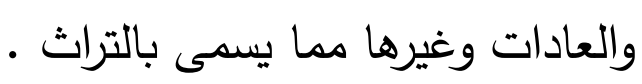

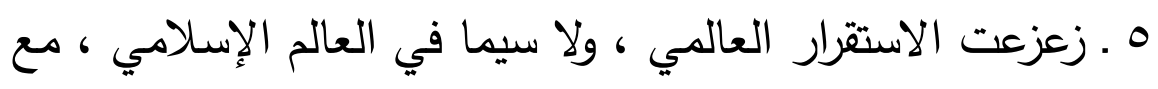

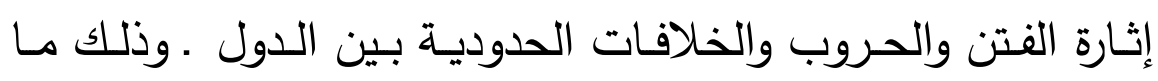
حدث في هذه الآونة الأخيرة من حدود مع المملكة السعودية وأيضًا

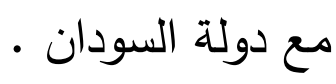

وذلك لخلق بؤر توتر في العالم لمصلحة الدول الغربية وعلى رأسها

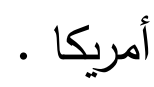

7 ـ تغيير جغرافية العالم من خـال القضاء على بعض الكيانات

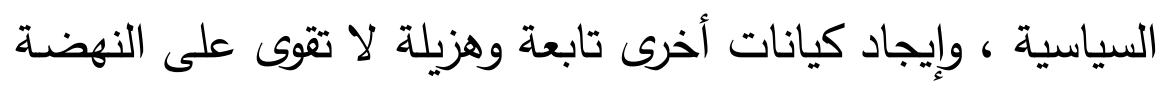
ولا على مقاومة هجمة العولمة بشتى مناحيها . 
V . فرض استعمار من نوع جديد يمكن أن نسميه استعمار القرن

الحادي والعشرين (') (1)

A ـ تحويـل الغالبيـة السـاحقة من النـاس إلى مسـتهلكين يستجيبون لسـلع معروضـة دون تدبر ، وهذه الاسـتجابة تنتج أنماطًا سـلوكية

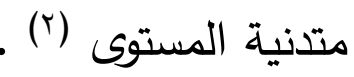

وقد أشار بوضوح إلى أهم أهداف العولمة ، الكاتب الأمريكي "

ديفد روشكويف" وزميله "داني رودويك" اللذان قررا ـ بوضوح شديد . أن هدف العولمـة هو سيطرة أمريكا على العالم كله سيطرة تشمل

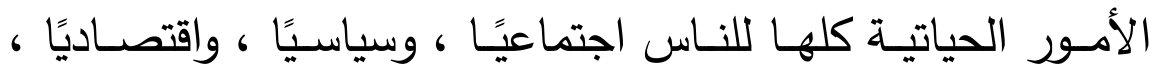
وخلقيًا .. . الخ ، بل إن الكثيرين من الكتاب الداعين إلى العولمـة

يطالبون بتطبيقها بالقوى .. . (r) .

وهذا يعني أن العولمـة تهدف للقضـاء على الدين عقيدة وشريعة وثقافة وحضارة ، وقيمًا وأخلاقًا لدينا نحن المسلمين . وتحويلنا إلى نسخ مشوهة تابعين للغرب في ثقافتتا وحضـارتنا وأخلاقنا ـ بعد أن كنا تابعين لهم اقتصـادًا وسياسـة فقط .وذلك عن طريق الدعوة إلى

(') العولمـة أم عالميـة الثربعة الإسـلامية ، محمد عمر الحاجي صـ اء ـ بـ؛ ،

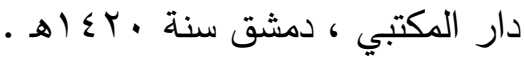

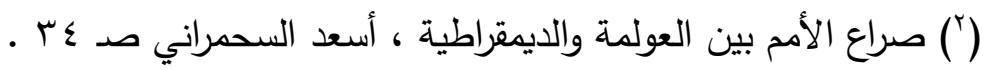

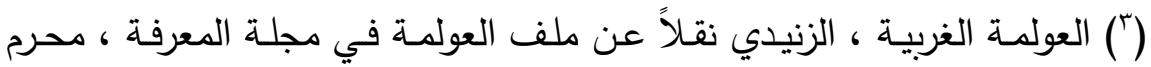
وصفر سنة . rع أهـ ، بتصرف . 
وحدة الأديان ، وهي دعوة خطيرة تتتافى مع أصول الإسلام ، لأن

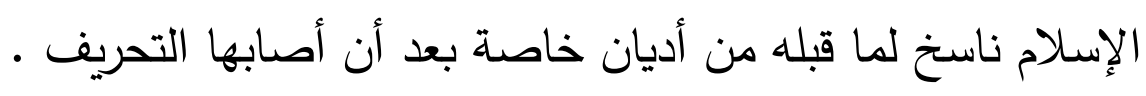
وأيضًا تهديد النظام الأخلاقي الإسـامي بإباحة الشذوذ وحمايته

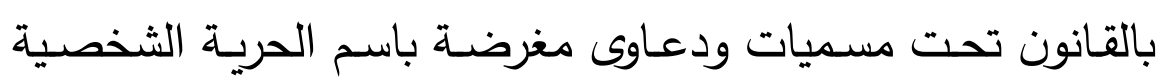

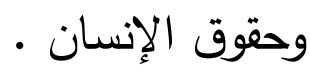

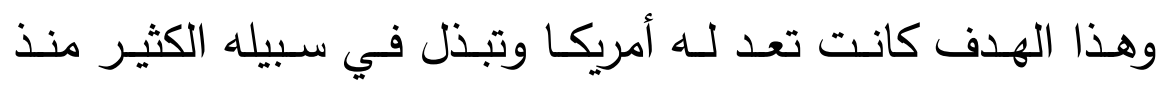

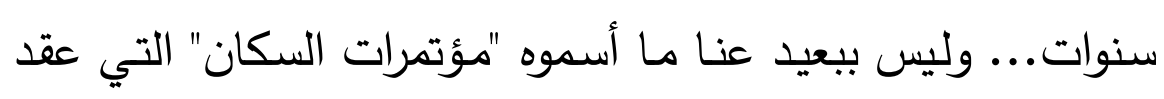
بعضــها بمصـر ، وبعضـهـا بالصـين .. . وهـذه المـؤتمرات مثنـال واضـح من الوسـائل التي أخذ الغرب وأمريكا في استعمالها فعـلاً

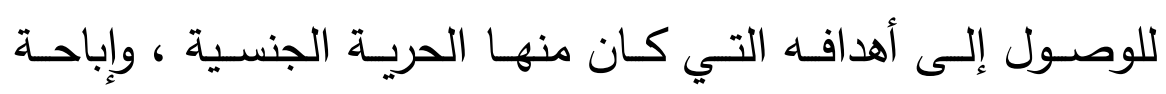

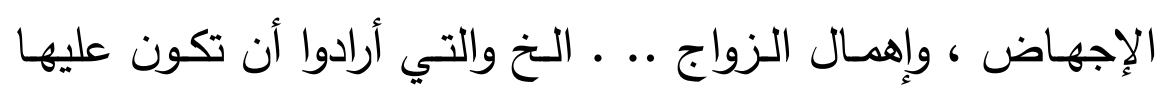

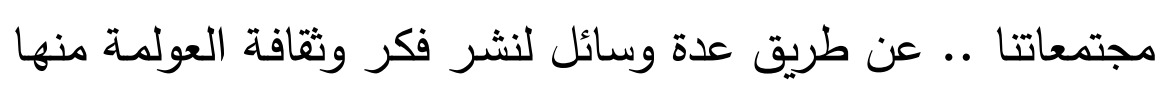

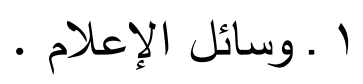

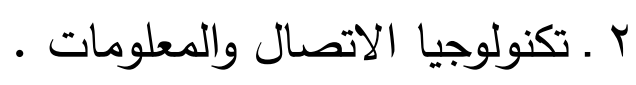

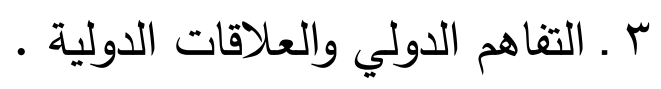

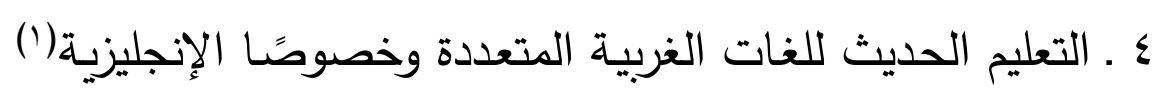

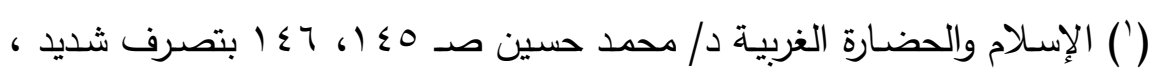

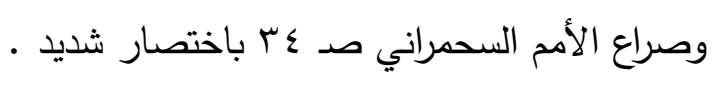


وأخيرًا يمكن أن نذكر أن المقصود والهدف من العولمة هو نشر

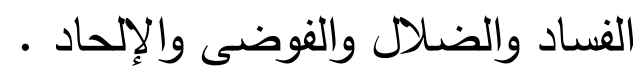

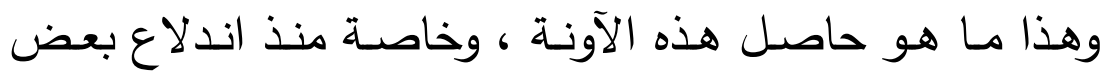

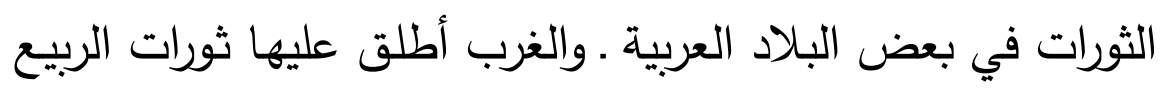




\section{الإلبب الرابع}

\section{هبالات العمهلة ـ أبعادها .}

للعولمــة عدة مجـالات ـ أو أبعـاد ـ خاصــة مـا يتعلق بتراثنـا

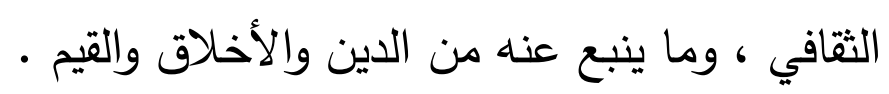
ولهذا سوف أبدأ بأخطر مجالات العولمة وهي :

\section{ا ـ العولة الثقافية :}

هذا الججال من أخطر الدجالات .. لأنه دين يذهب ، وأخلاق تنسد ، وهوية تذوب ، ومن ثم فناء حضاري .

ومن البديهي أن ثقافتتا الإنسلامية ، ثقافة نوعية متميزة ، لها فها تنردها وخصوصيتها .. حيث أن مصادر وموارد ثقافتتا هي الوحي

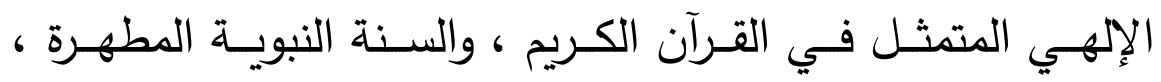

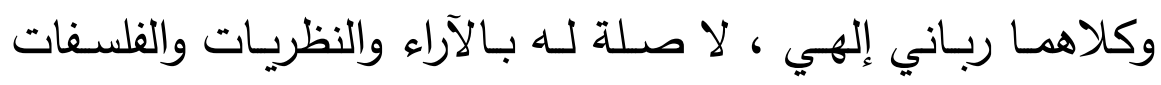

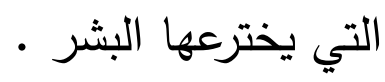

ولذلك ثقافتتا ينتج عن تميزها جانبان هامان :

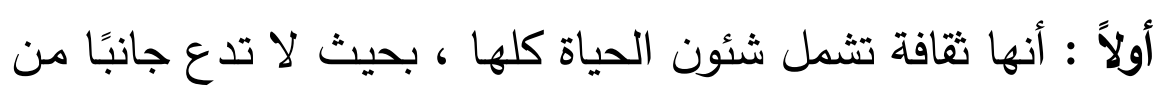
حياة الإنسان المسلم صغيرًا أو كبيرًا إلا والإنسلام قد شرع له له وشمله 
ثانيًا : أنها ثقافة . حيث مصدرها وموردها القرآن والسنة ـ ينظر إليهـا المسـلم نظرة تقديس وتعظيم وإجـال ؛ لأنها ديـن ، والدين وحي من الله . سبحانه وتعالى ـ فالمسلم لا يأخذ أو يدع إلا بتشريع

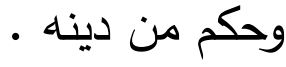

وهكذا يكون الاعتداء على الثقافة الإسـلامية ممثلاً في العولمة

؛ هو اعتداء على دين الله الذي يدين به المسلم (') .

ويمكن تحديد مظاهر العولمة الثقافية فيما يلي :

1 ـ تغييب الأساسيات الدينية ، سواء كانت مبادئ إيمانية أو أحكام

شرعية تحت

وطأة الفكر الإحادي ، والنظريات المنحرفة عن الحقائق الدينية أو عن طريق الاستخفاف بها ، وما تمثله من حق مطلق • r ـ تحريـف المفـاهيم المنبثقـة مـن ثقافـة الأمـة ، وتثـجيع التهـرد

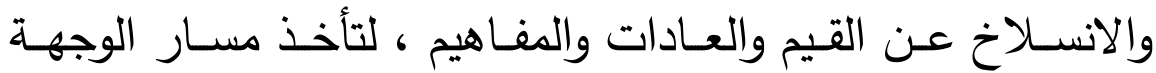
الغربية في النظر إلى الحياة .

r ـ ـومـن المظـاهر أيضًا ، الخـروج بـالمرأة عـن أنوثتهـا الفطريـة

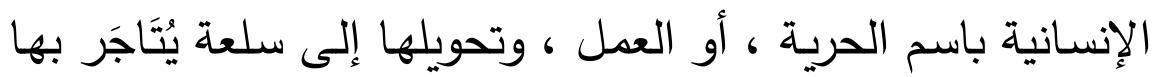
، ووسيلة جذب في تقديم البرامج الإغرائية في القنوات الفضـائية

(') الإسلام والحضارة الغربية د/ محمد حسين صده ا، بـ ا ، بتصرف شديد . 
واختلاطهـا .. . وأيضًا في الــعايات وعلى أغلفـة المجـلات .. ودفعها إلى منافسة الرجال ، والتحرر من الالتزامات .

ـ ـ جَعْل اللغة الإنجليزية هي السائدة على حساب اللغات الأخرى . وخاصة العربية .

ه ـ استغلال النخب المثققة المتغربة ـ وهم كثير منهم أمريكو الثقافة . اختير بعضهم ، لما يتوسم فيه من القدرة على توجيه التفكير في

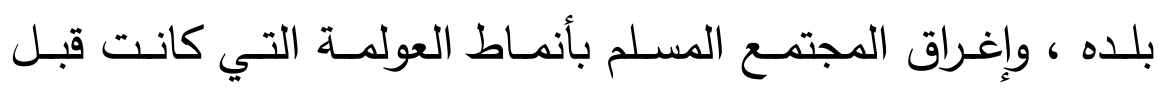

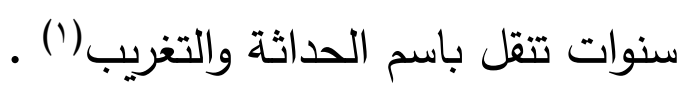

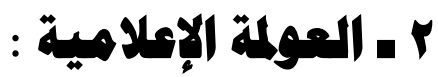

تهدف عولمـة الإعـام إلى التأثير في المتلقين الذين ينتمون إلى مي ثقافات متباينة .. .

ولا شك أن تكنولوجيا الاتصال والمعلوماتية (الانترنت) وفرت مئات القنوات الفضائية ، ومئات المحطات الإذاعية ، وغيرها .

وكل ذلك يشكل تهديدًا للتعددية الثقافية ، وعدوانًا سـافرًا لمبدأ

احترام الهويات الثقافية للشعوب المختلفة ـ وكل هذا لصـالح المزيد

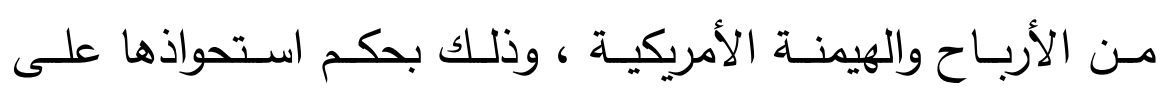

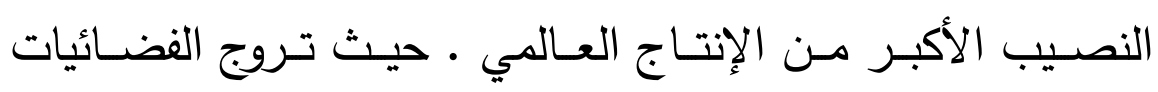


الغربيـة والأمريكيـة لمنظومسة قيميـة ، وخاصـة مـا يتعلق بـالمفهوم الغربي للحريـة الشخصية ، ومـا تحمله مـن ترويج للعـرى والمثليـة الجنسية ، وغيرها ـ والتي يتحفظ العالم الإسـلامي على قدر كبير من قيمها ، بل ويرفضها جملة وتفصيلاً (') . ب ـ العمولة ومقوق الإنسان : مـن أهـم مــا أفرزتـهـ العولمــة في الســوات الأخيـرة ، الاهتمــام بحقوق الإنسـان ، تلك القضية التي خرجت مـن الدائرة الوطنيـة والمحلية ، في دول العالم إلى الآفاق الدولية ، واعتبارها مسألة تهم

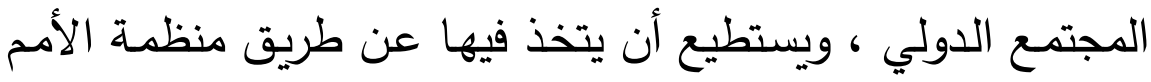

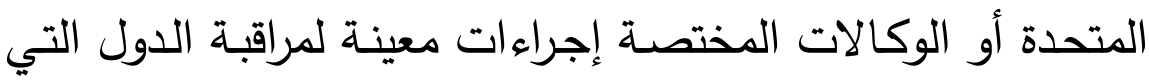

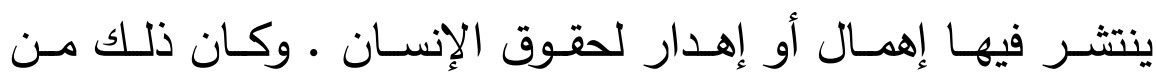
الأسباب التي دعت إلى إصدار الميثاق العالمي لحقوق الإنسان

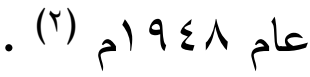
مع أن الإسـام سبق المواثيق الوضعية في إرساء مبادئ حقوق الإنسان ، واحترام الثخصية الإنسانية بكفالته لحريـة الفكر وحريـة

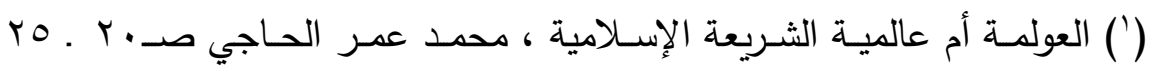
(بتصرف شديد).

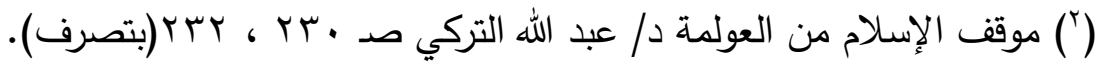


التدين ، والحريـة السياسية وإرسـائه لمبادئ الثـورى والحق والعدل

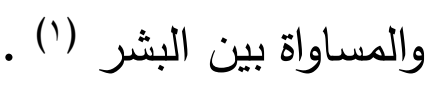

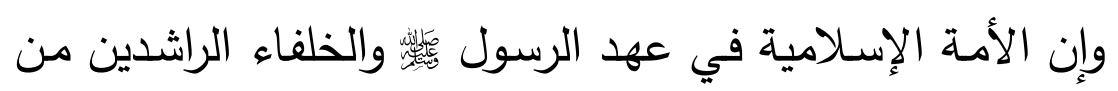

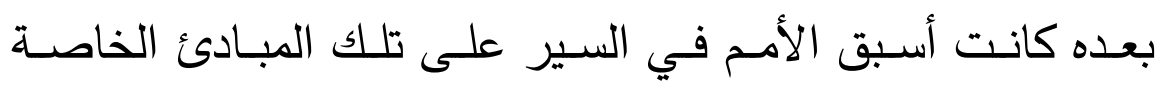

بحقوق الإنسان ومراعاتها (r) .

فحقوق الإنسان في التصور الإسـلامي بهذا المعنى ملزمة لكل

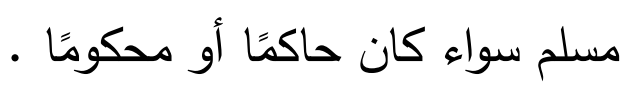

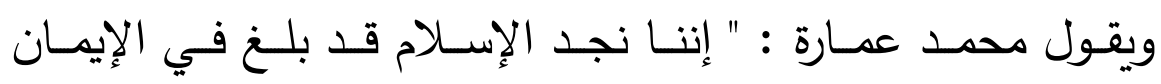

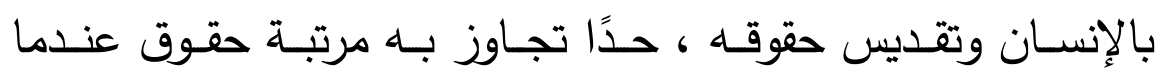
اعتبرها ضرورات، ومن ثم أدخلها في إطار الواجبات " (r) . فهو . محمد عمـارة ـ يذهـب إلى اعتبـار حقـوق الإنسـان في

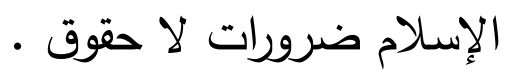

وبذلك فالإنسان يحمل في ذاته تكريدًا إلهيًا بكونها إنسانًا بغض أنس النظر عن جنسه أو دينه أو لونه .

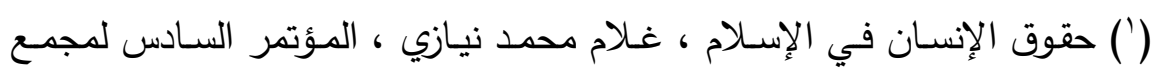

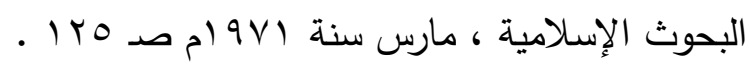

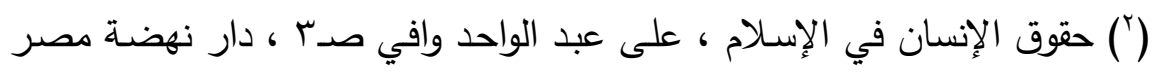

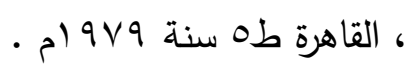

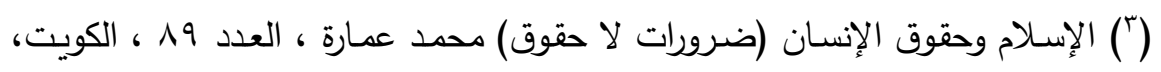

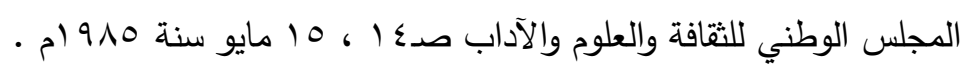


واليوم تتشدق العولمة بحقوق الإنسان ، والحفاظ عليها وحمايتها ، فإذا نظرنـا إلى الثقافة المؤثرة في العصر الحسالي في صياغة مفهوم حقوق الإنسان ، فإذا هي بـلا مراء الثقافة الغربية الليبرالية

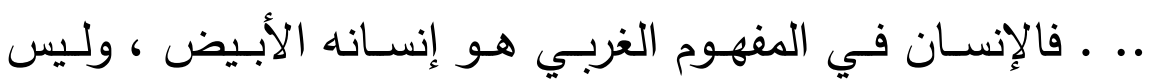

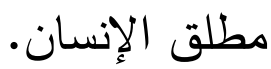

والحقوق بمفاهيمها الغربية هي وقف على هذا الإنسان الغربي قبل سواه ، وفي أحيان كثيرة دون سواه .

فحق تقرير المصير مـ الحقوق الطبيعيـة للإنسـان .. ـ لكن

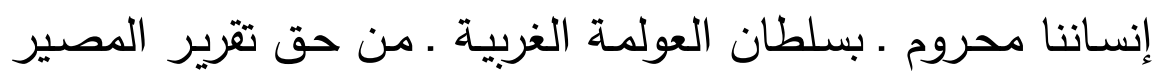

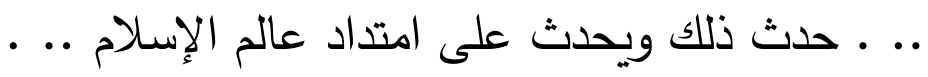
ذلك هو حـال العولمـة ـونمـاذج لهذا الحـال ـ في منظومـة حقوق (') (الإنسان (1) 


$$
\begin{aligned}
& \text { العولمة أبعادها وكيفية مواجهتها وموقف الإسلام منها } \\
& \text { المبحث الثاني } \\
& \text { الآثار السيئة للعولمة وكيفية }
\end{aligned}
$$

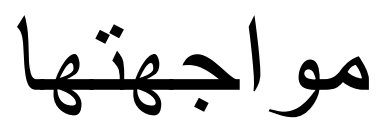

$$
\begin{aligned}
& \text { وفيه هطالب : } \\
& \text { المطلب الأول : الآثار السيئة للعولمة . } \\
& \text { المطلب الثاني : العولمة فى إطار الإسلام . } \\
& \text { المطلـب الثالـث : مواجهـة الإســلام للعولمــة }
\end{aligned}
$$

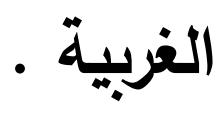




\section{الإطبا الأول}

\section{الآثار السيئة للعوكلة}

يقول الألمانيـان "هـانس بيتر مـارتين وهارولـد شـومان" صـاحبا

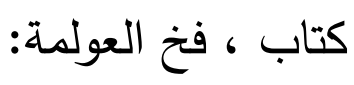

مع نمو العولمة يزداد تركز الثروة ، وتتسع الفروق بين البشر وبين

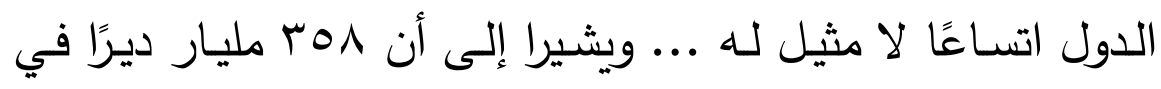

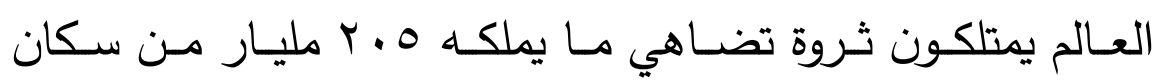

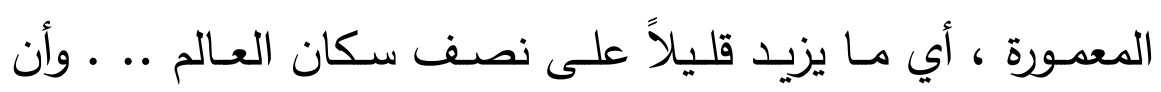

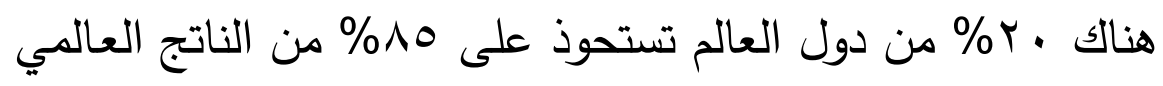

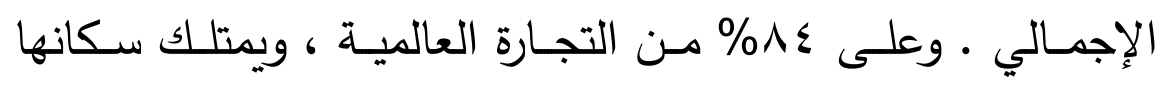

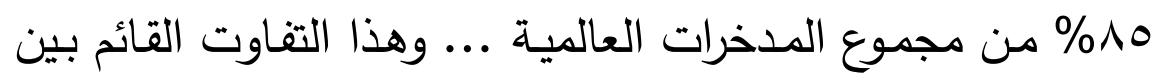

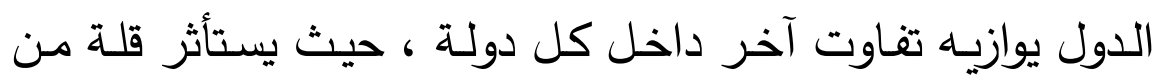

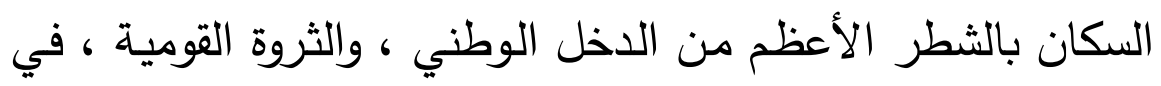

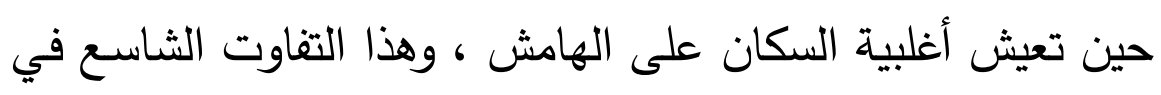

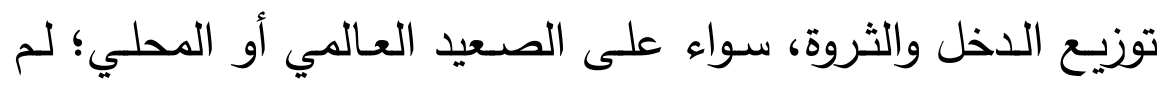

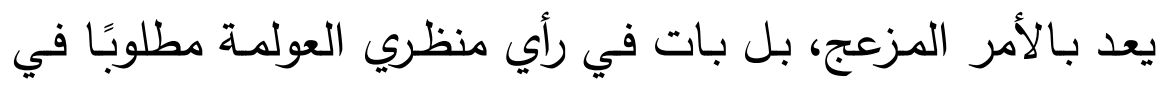

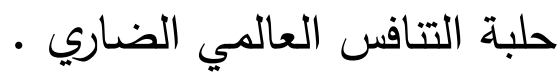


ويقرر الكاتبان بقولهما : فالزعم بأن أمريكا تساعد باقي العالم في حل مشاكله حبًا في الخير ولوجه الله لا غير ؛ هو زعم باطل

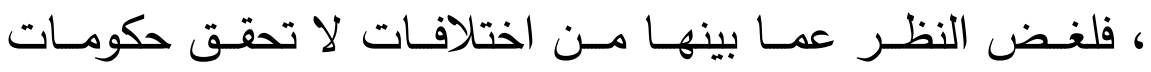
الولايات المتحدة منذ قديم الزمان إلا ما تراه يخدم مصلحتها القومية

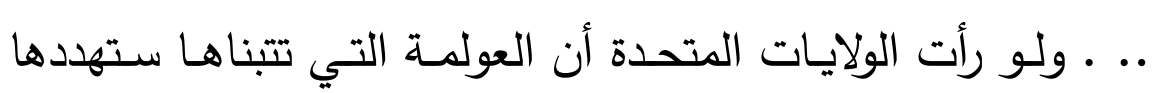

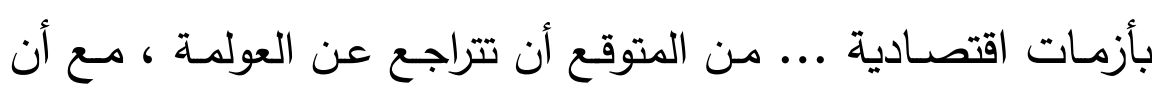
ذلك البلد على وجه الخصوص هو الذي حمل العالم على الخضوع

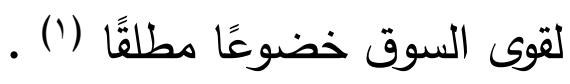

وإن المتأمـل في أحوال العـالم اليوم يجد أن نشـاط النـاس فيـه

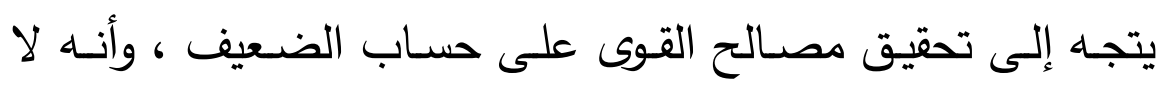
يوجد في العـالم من يبـل جهدًا يـكر لتحقيق العدل ، ومســاعدة الضعيف ، وتحقيق التوازن بصورة من الصور النافعة بين الناس . لا شكك أن هذه الآثار السيئة مرعبـة ومفزعـة وغير إنسـانية ، وأنها

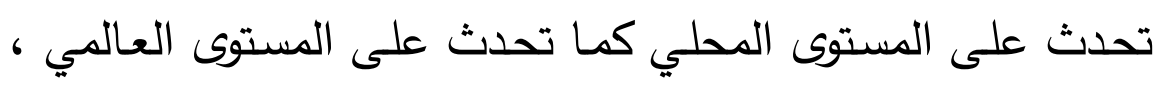

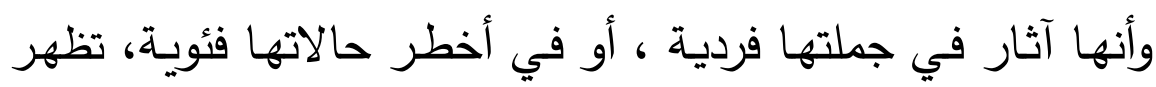
بين فئة وأخرى على مستوى الدول أو الأمم أو الجماعات.

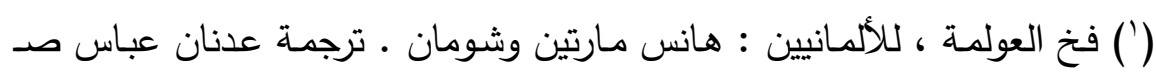

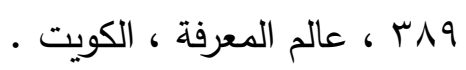


وهذه هي الآثار والنتائج الحتمية لما يسمى "العولمة" التي أرادها

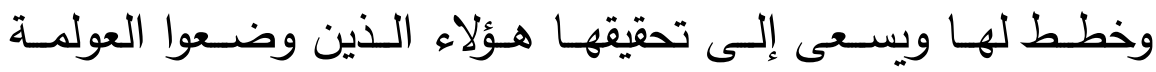
ويروجون لها بين الثـعوب والدول ، بكل وسـائل الضـغط لإجبار

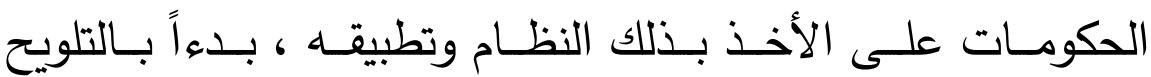

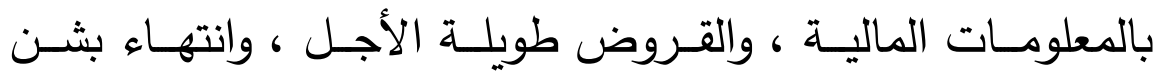
الحـروب الاقتصـادية والسياسـية، وغيـره كثير ـ أسـلحة يستعملها واضعوا هذه النظام الفاسد لإجبار الدول على الأخذ به ، وبخاصـة وليه

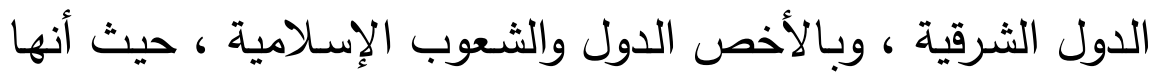

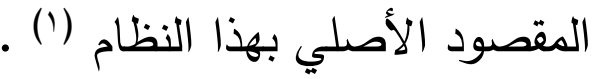
ويمكن إجمال هذه الآثار السيئة للعولمة فيما يلي : 1 ـ الآثرة المادية والرغبة في الاستحواذ على أقصى قدر ممكن من خيرات الكون ـ أي لغزو اقتصادي. r ـ استعمال القوة لتحقيق السـيادة وهـو مـا يـؤدي إلى الحـروب

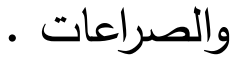
r ـ الإعـام الموجه لخدمة مجموعـة من الناس بعيدًا عن الطريق الموصل إلى الحقيقة .

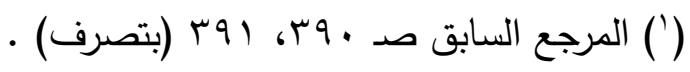


العولمة أبعادها وكيفية مواجهتها وموقف الإسلام منها

1106

عاحتكـار المعـارف والاختراعـات والتجـارب والمعلومـات لمنـع

الآخرين من اللحاق أو التتافس باختيار •

ه ـ التعالي بالجنس أو القوة والمبالغة في إيذاء الخصوم ـ أي عدم

إنسانيته . . (1)

7 ـ وأخيرًا الضغط والإكراه لتغيير الدين ، أو فرض المذهب ، أو

الإجبـار على سـلوك معـين ـ أي السـعي للقضـاء على الإسـلام

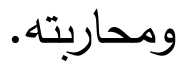




\section{(c) ithl}

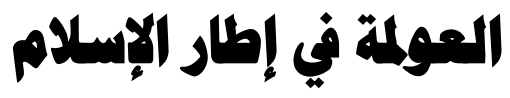

منذ صـدر الإسـلام، وحتى العصـر الحديث ، لـ يتوقف تواصـل المسـلمين مـع غيـرهم. وقـد شـهد العـالم تغيـرات هائلــة في القـرن السابق في ظل تقلص القوى العالمية ، وتسليم العالم زمام أمره لقوة واحدة تقـوده دون جـارة ، أو اسـتحقاق ، وهـي الولايـات المتحـدة الأمريكية في ظل ما يسمى بالعولمة .

والغرب يصدر في سعيه للقضاء على الإسلام عن عداء بغيض

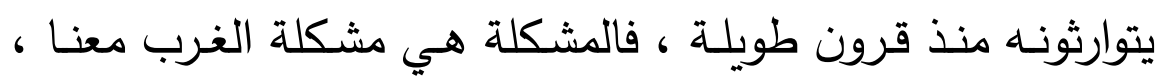
والعداء عداؤه لنا ؛ لأنه يرى حضارته الحضـارة الإنسانية الوحيدة ، فيسلك كل السُبل لفرض نموذجها على العالم "لا كرسالة حضـارية" مجـردة ـ وإنمـا كسبيل وآليـة مـن سـبل وآليـات الإلحساق السياسـي والاقتصـادي والعسكري ، إنها يريــ في الحضـارة كما في السياسـة والاقتصاد والأمن تابعين ، بل وعملاء لا أندادًا وشركاء .

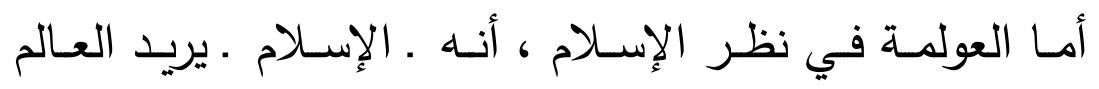
"منتــدى حضــارات" تتفاعـل دون تبعيــة وإلحــاق ، ودون عـداوة 
وانغلاق ، وذلك لأن دينتا ـ الإسـامي يعلمنـا أن مـا عدا الذات

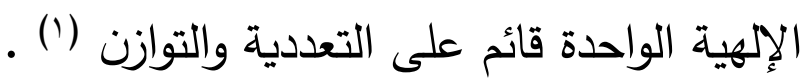

ففي الشرائع تعددية :

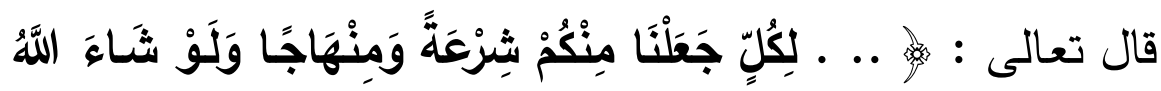

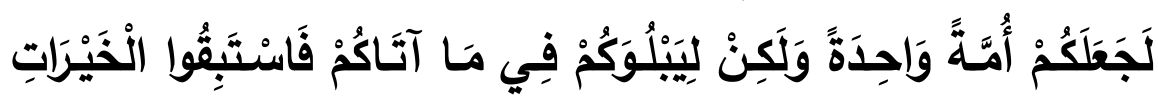

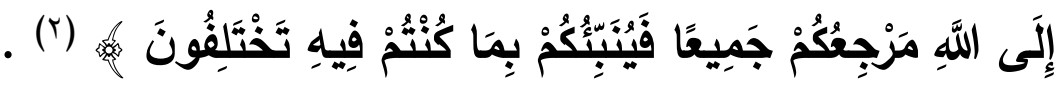

وفي الألسنة والألوان ـ أي في القوميات والأجناس ـ تعددية :

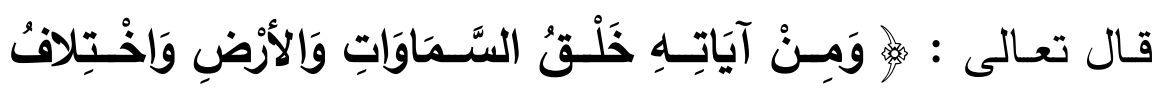

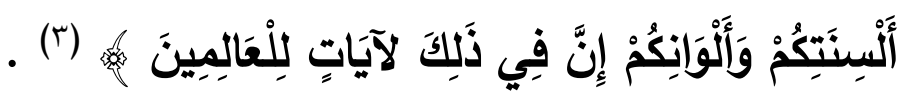

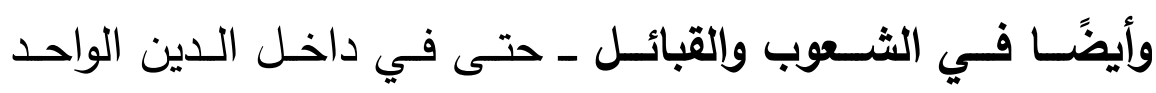
والحضارة تعددية :

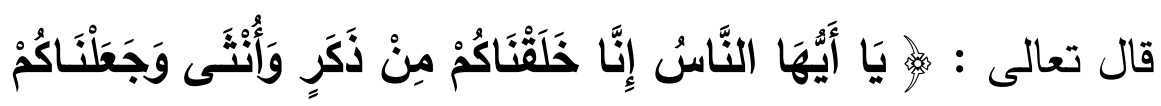

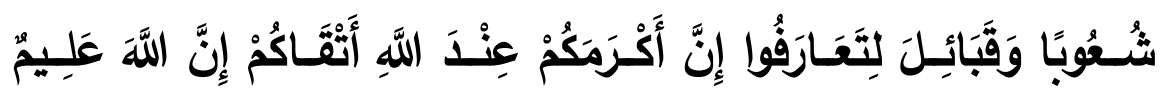

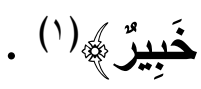

(') دور التربية الإنلامية في تتمية الثخصية المصرية لمواجهة اللانظام العالمي

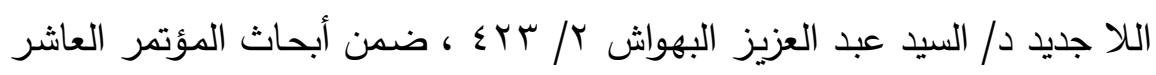

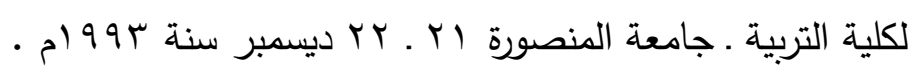

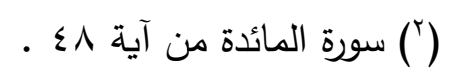

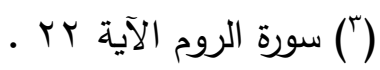


فالأصـل في النظـرة الإنسـلامية هـو "التعدديـة" ، والاعتـراف

بالآخرين، وما يريده المسلمون هو قبولهم كأصحاب هويـة حضارية

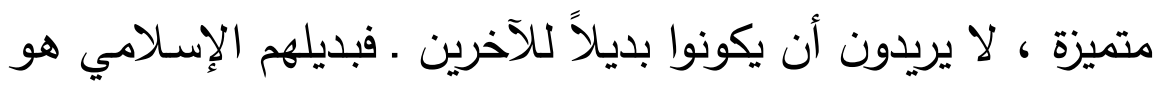

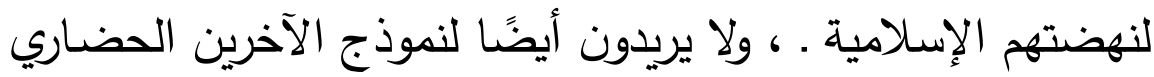

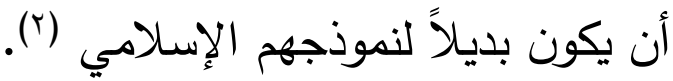

من هذا يظهر جليا أن الإسـلام عـالمي الرسـالة ، بمعنى أنـه

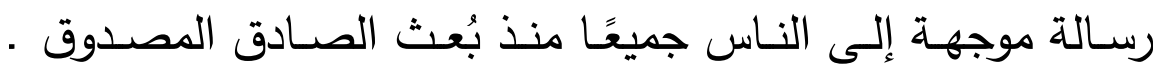
صلوات الله عليه وسلامه ـ وإلى أن يرث الله الأرض ومن عليها . وهــا المعنـى تؤكـده آيـات القـرآن العظيم ، قــال عـز وجـل

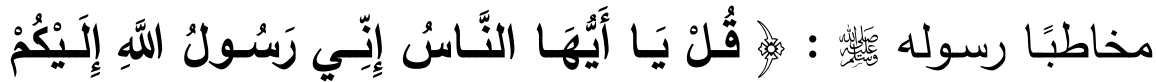

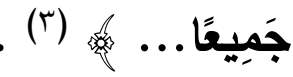

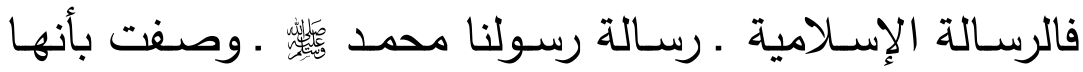
موجهة للناس جميعًا ، وللعالمين • بينما الرسالات الأخرى السابقة

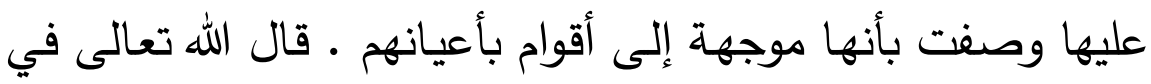

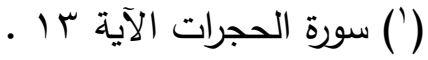

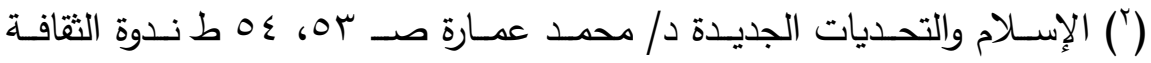

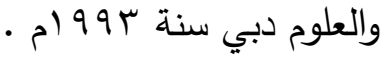

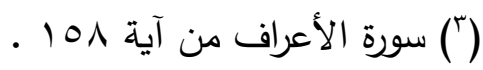




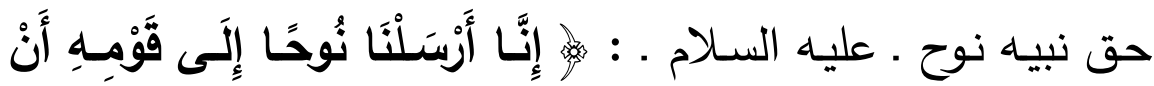

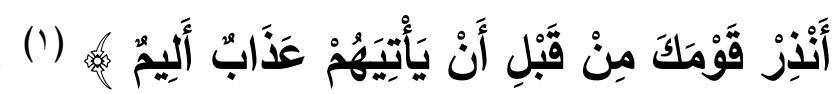

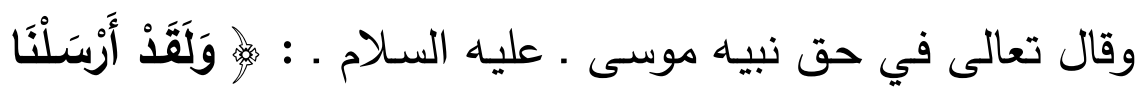

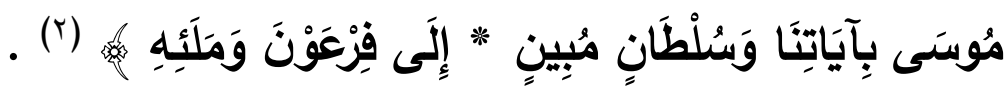

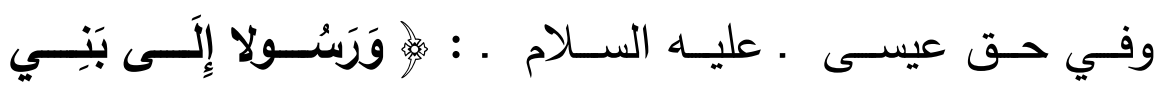

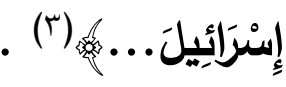

وهكذا كل الأنبياء .. ـ كانت بعثتهم إلى أقوامهم خاصـة ،

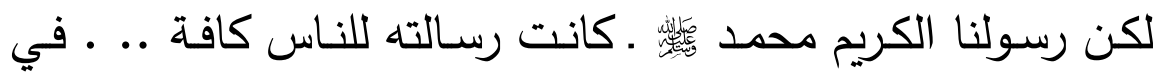

الصحيحين عن أبي هريرة ـ رضي الله عنه ـ قال : قال رسول الله

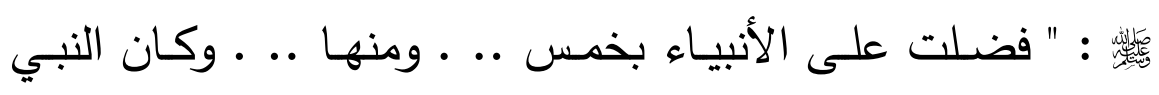
يبعث إلى قومه خاصة وبُعثت إلى الناس كافة " .

والآيات والأحاديث في ذلك كثيرة .. . " والفرق واضح بين هذه

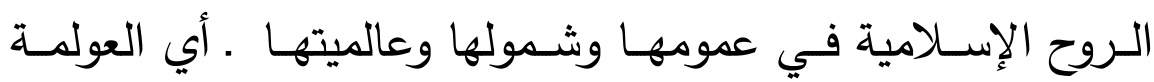
بالنظرة الإسلامية . التي تزيل كل إحساس بالتثوق على أساس من

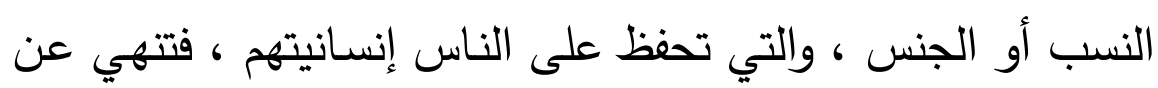
قتل الأسير ، وتمنع في الحروب من التعرض للنسـاء والثنيوخ

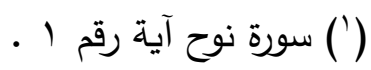

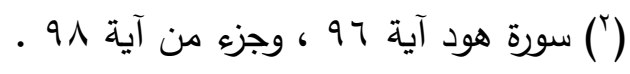

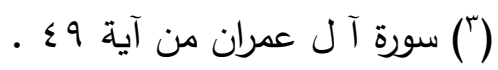


والأطفـال . غيـر المقاتلين . وتحرّم إجبـار اليهود والنصسارى على ترك دينهم ، وتمنع من هدم دور عبادتهم أو المساس بها ، وتأمر بإقامة العدل بينهم وبين المسلمين .. . فالغرق واضـح بين الإسـلام في روحه الإنسـانية هذه ، وفي عالميته الشـاملة ، وبين العنصرية اليهوديـة التي تعتبر الدين اليهودي مقصـرًا على بني إسـرائيل لا يتعداهم إلى سواهم ..

والإســلام عـالمي ؛ لأنـه يـربط بـين الدين والدولـة فمهمـا تفرق المسلمون في الأوطان والأجناس ، ومهما توزعتهم الدول والحكام ، فالدين وشـريعته يوحدهم ويجمعهم على أنمـاط مشـتركة ، وأذواق متقاربـة ، ونظـم إجتماعيـة واقتصـادية واحدة ، لا يحق لمسـلم أن يخرج على نصوصها الصريحة بتأويل أو تعديل" (1) . وتوجد مزايا خاصة جعلت الإسلام عالمي الرسالة منها :

\section{1}

بمعنى أن مصدره القرآن الكريم الذي لا يأتيـه الباطل من بين يديه ولا من خلفه وأيضًا المصدر الثاني هو سنة الرسول العظيم 


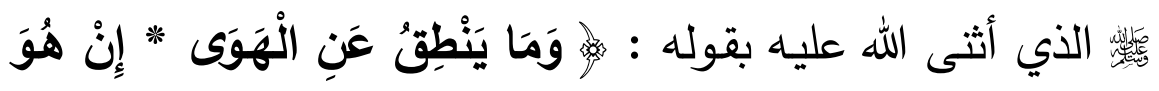

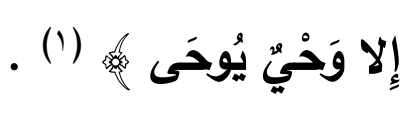

فالإسلام مصدره القرآن والسنة فهو دين سماوي ليس من وضع

\section{Y ب . عموم رسالته :}

فالرسول 先 ، أرسل رسائله إلى الملوك يدعوهم إلى الإنسلام ،

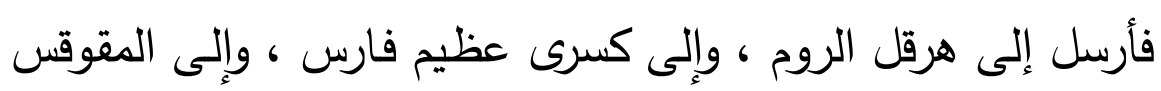

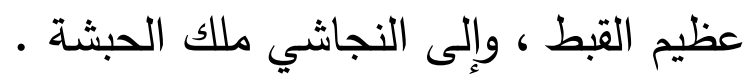

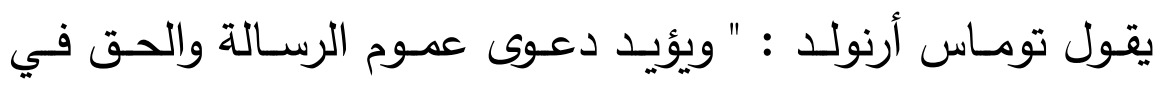

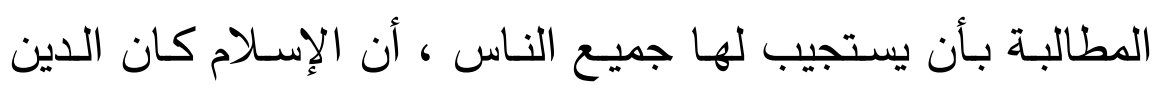

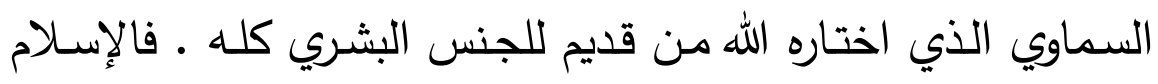

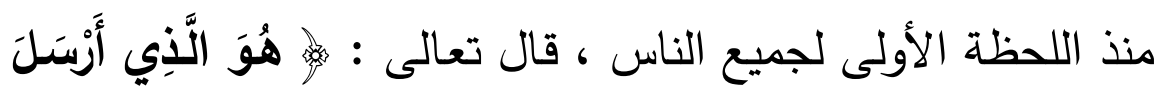

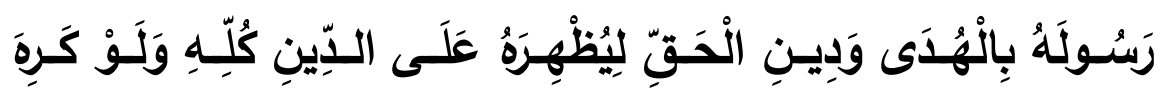

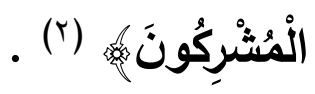

بـ ـ شمولية الرسالة :

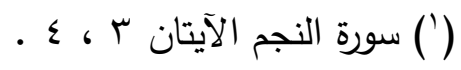

(') (') سورة الصف الآية 9 . 
إن الإسـام دين شـامل لكل شئون الحياة ، فهو رسـالة وديـن لكل الأزمنة والأجيال ، وليست رسالة موقوتة بعصر معين أو زمن زئن

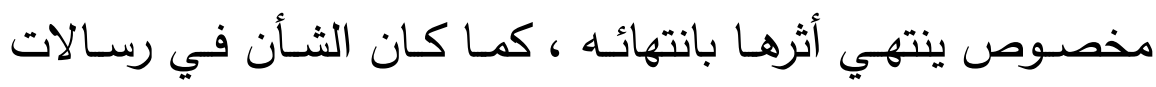

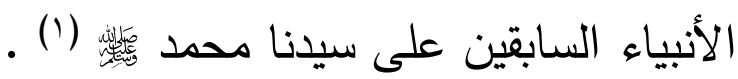

\section{ع ـ الرسالة الخاتمة :}

أجل !! إنهـا الرسـالة الخاتمـة التي بلغـت بالبشـرية إلى مرحلـة

الرشد والكمال ـ ومن ثم جاءت جامعة لكل معاني الخير والبر .

وهكذا يتقرد الإسـلام بخصائص ومزايا لا مثيل لها في أي نظام

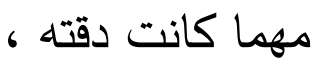

إنـهـ ـ الإســلام ـ النظـام الوحيد الفريــ الذي يلبـي حاجـات البشرية

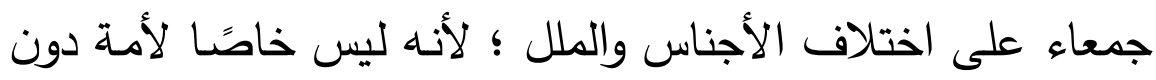

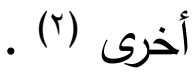

وإذا نظرنا إلى أي نظام آخر نجد السمة البارزة فيه مبدأ النفعية

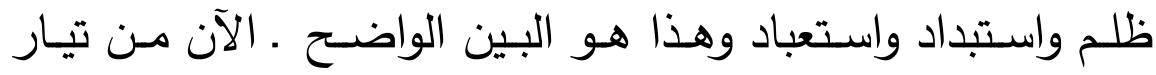

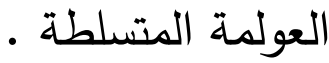

(') الخصائص العامة للإسلام د/ القرضاوي صد9 9 .

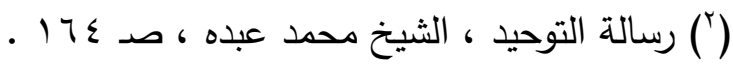


هذه هي وجهة نظر المسلمين ، والاعتراف بالآخرين • ولكن العالم ـ اليوم • يبحث عن عدو جديد ، ولا يجد الغربيون حرجًا في لهاي

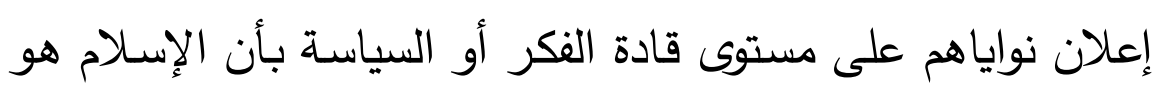
هدف الحملة الغربية الجديدة ، ليس لسبب سوى أنه الثقافة الوحيدة القادرة على توجيـه تحدٍ فعلي وحقيقي لمجتمعات يسودها مذهب هـبـ اللإرادية ، وفتور الهمة واللامبالاة ، وهي آفات من شأنها أن تؤدي وهئي

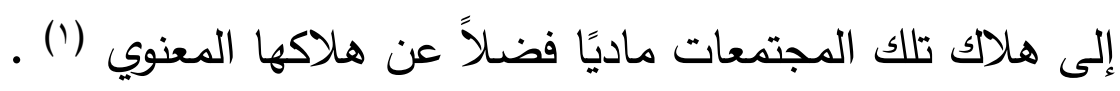

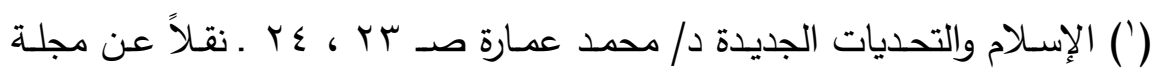

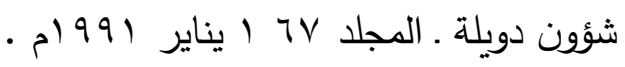


حولية كلية الدراسات الإسلامية والعربية بنين بالقاهرة العدد (r م؟)

\section{الإلبب الثالث}

\section{مواجمة الإسلام للمولة الغربية}

إن المسلمين ـ بصفة عامة ـ عليهم أن يبذلوا قصارى جهدهم في التواصل مـع العالم في عصر العولمة ؛ بالتعامل بلغته ، والإفادة

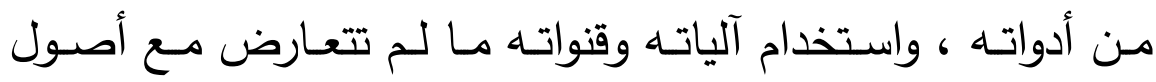
دينهم ، ومرجعيتهم الشرعية . والمثقفون من المسلمين عليهم عبء مضـاعف ، فهم مطالبون بالـدخول إلى هذا العصـر (العولمـة) بهـف التعريـف بالإســلام ، وتصـويب الفكر المنحرف في وعي وعقول غير المسـمين عن

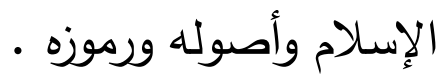

فالمسلمون في مواجهة العولمة يملكون عقولاًا ، ويملكون أموالاً ، ويملكون خبرات في جميع مجالات الحياة ، ويملكون من القيم

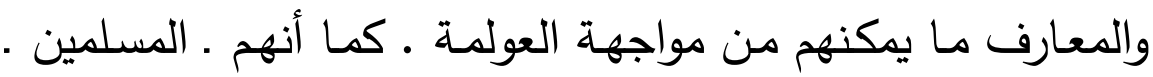
يحملون من القواعد الدينية ما يكفل سعادة العالم في ظل العولمة . فهناك أسس وركائز أساسية يجب الانطلاق من خلالها لمواجهة

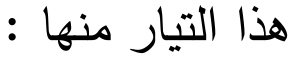


ا ـ العمل على تحقيق الخيريـة التي حبانـا الله تعالى بها في قوله: 

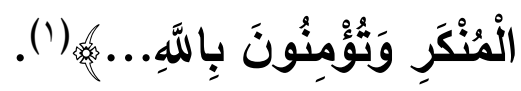

Y . إن الله تعـالى ربـط بـين المسـلمين ، ووحـد بينهم بـأوثق ربـاط وأعظمهـ إلا وهو ربـاط الإيمان ، وأعلن القرآن الكريم مبدأ الأخوة

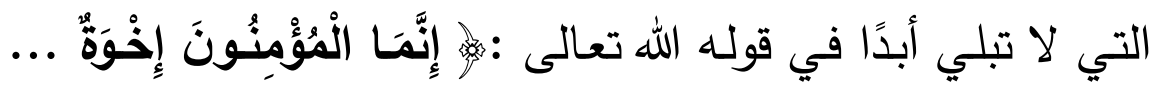
. $(r)$

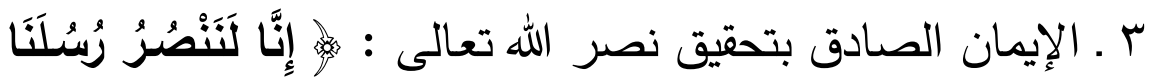

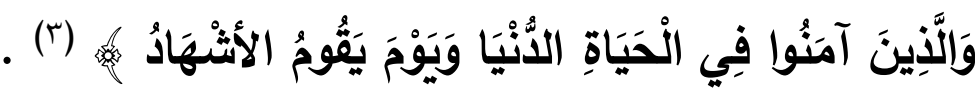

ومن أهم الأسس التي يجب الاعتماد عليها في مواجهة العولمة .

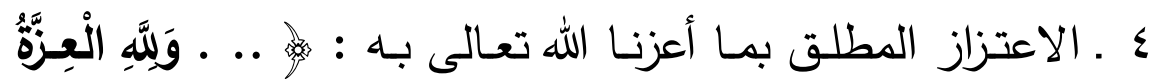

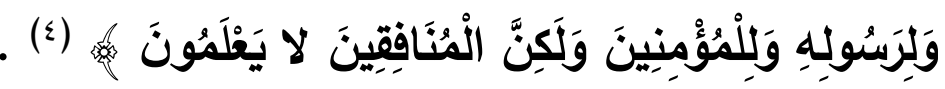

ه ـ اليقين بـأن الحـق والباطل لا يلتقيـان أبـدًا .. ـ فالصـراع بيـن الحق والباطل قائم إلى أن يرث الله الأرض ومن عليها ... فالحق

(') (1) سورة آل عمران من آية (1)

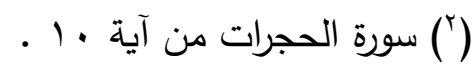

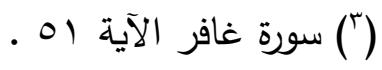

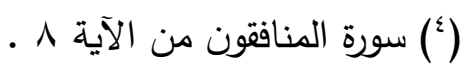




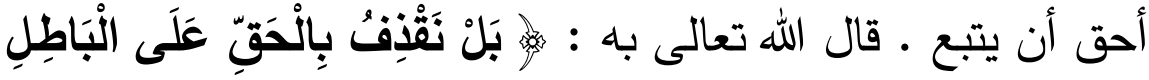

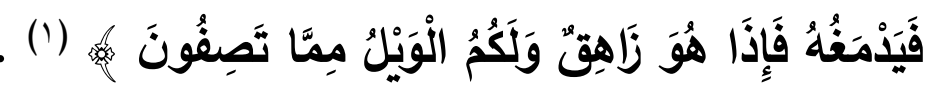

فمواجهة العولمة تتطلب العودة إلى الفكر الإسـلامي ، المستتد

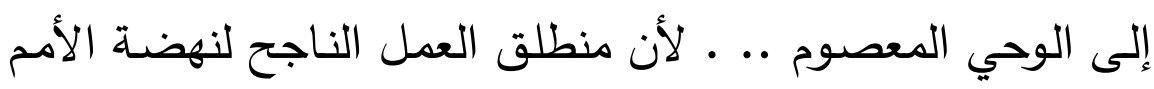

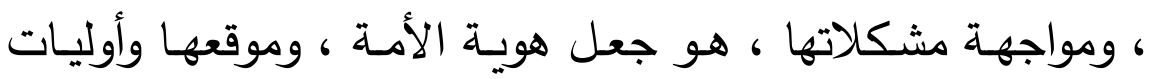
حاجاتها منطلق التفكير والدراسة والعلم والعمل الجاد ، والنظر فيما يُجدّ في ساحتها من مقذوفات ثقافية وغيرها .

وخير مثال لذلك توجيه النبي

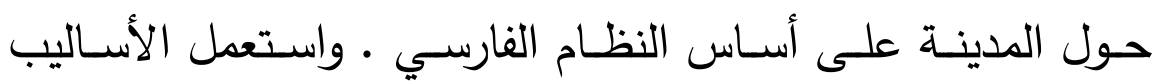

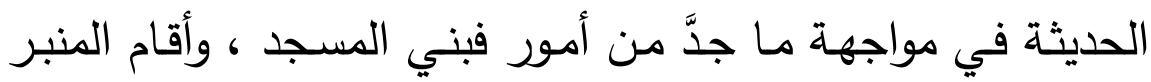
ونظم شئون الدولة على أسس تتاسب العصر ، وتحقق المقصود

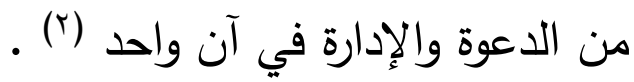

ولـتلك يوجـد خطـوات يجب السـير والاعتمــاد عليهـا لموجهـة

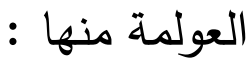
ـ أولًا الارتكاز على الهوية الإسلامية . r ـ استقلال القرار السياسي لقادة الأمة حكومة أو معارضة .

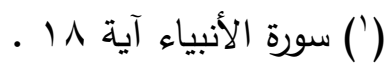

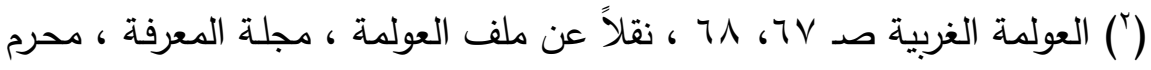

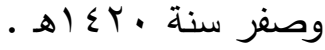


r ـ تحقيق التكتل الاقتصـادي والثقافي والإعلامي بين دول العالم

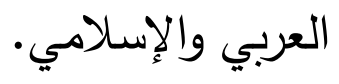

ع ـ تحقيـق النمـو الاقتصـادي التتمـوي المسـتقل الـذي تسـتهدف أولوياته غايتا الحضارية بعيدًا عن النموذج الاستهلاكي الغربي. ه ـ تحقيق استراتيجية المواجهـة الإعلاميـة والفكريـة ؛ مـن خـلال

التقدم التقني الإعلامي ، وإشعال الوعي الفكري (') .

لأنه لا معنى للتقوقع ، أو الانعزال ، أو الانغلاق بحجة الحفاظ على هويتنا ، وخصوصية ثقافتتا من غزو الفكر الوافد ، والثقافة

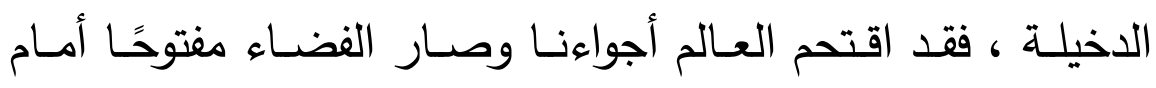
الأصيل والوضيع ، والصـيح والسقيم ، ومـن التهم الجاهزة التي

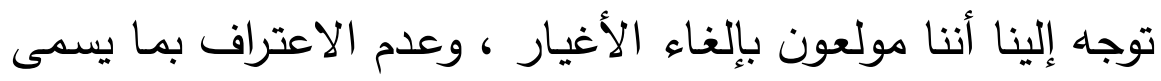
"بالآخر" وهي تهمة كاذبة ، يكذبها الإسـلام ويشبت عكسها نظريًا

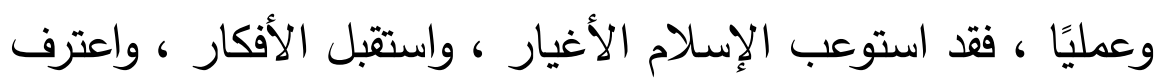

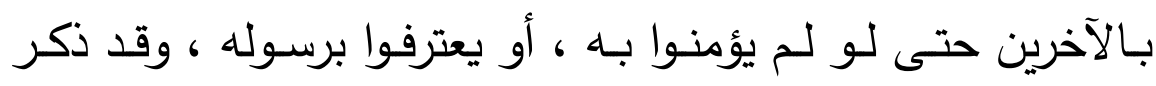

(') الإسـلام والعولمـة ، محمد إبراهيم مبروك وآخرون صـ 100 10 ، 107 ، الدار القومية العربية ، القاهرة طץ ( د ـ ت) . 
القرآن الكريم عقائد الآخرين وتصوراتهم قبل أن يعلن عتيدة التوحيد

وأخيـرًا لمواجهـة العولمــة ، الواجـب لنجــاح أي دولـة في ظـلـ

العولمة .. . الاهتمام بالسياسة الداخلية ، وتحقيق الأمن الغذائي ،

وتنظيم الحكومة تنظيمًا يتلاءم مع المتغيرات الدولية (r) .

(') التربية الإسلامية وتحديات القرن الحادي والعشرين صـ ع 1 1 ، 110 ، ضمن محاضرات المؤتمر التربوي الأول . جامعة السلطان قابوس . سلطنة عمان V. . 1. ديسمبر $99 \mathrm{~V}$

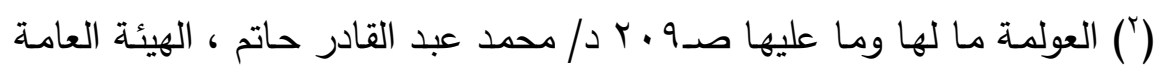

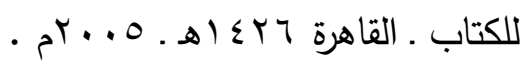




\section{الخاتمهـة}

وبعد هذا الجهد المتواضـع ، فيما يتعلق بهذه الظـاهرة (أو تيار

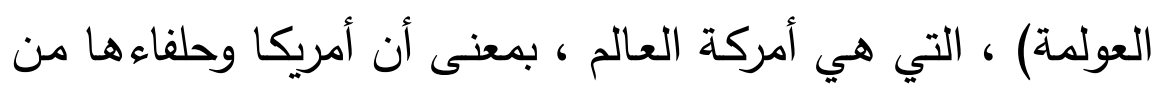

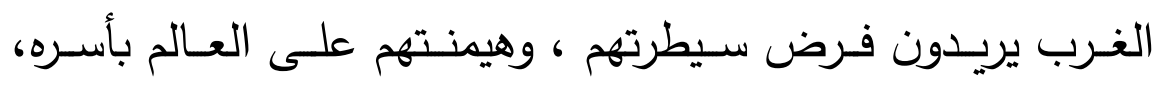

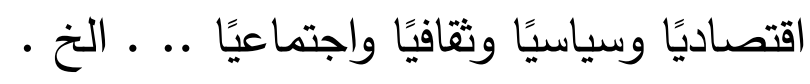
وُجد هذا أمرًا خطيرًا للغايـة ، ومما يزيد الأمـر خطورة لأن الأمـة

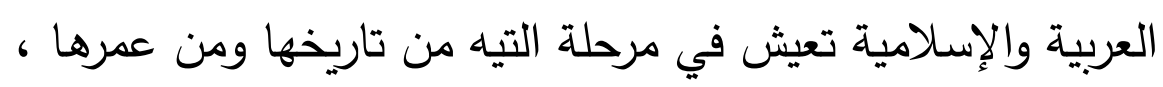

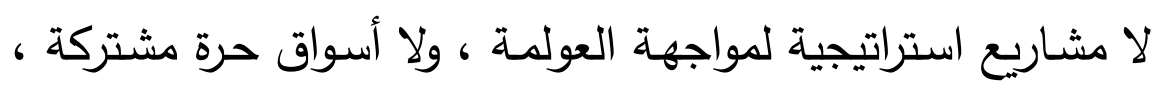

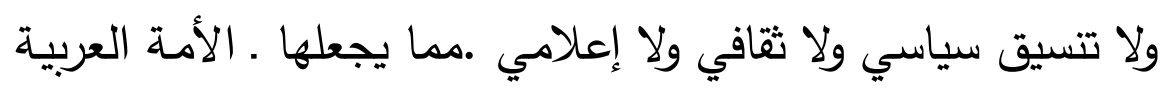

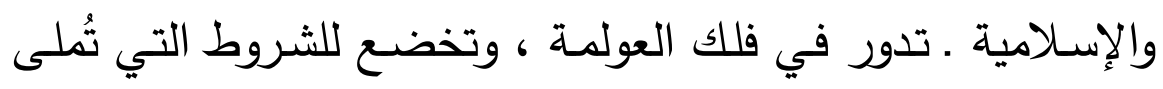
عليها ، وإن ضـحوا في سبيل ذلك بـالقيم والمبـادئ ، والمصـالح القومية العليا لشعوبهر •

\section{ـ من التوصيات والقترحات :}

1 ـ ينبغي توعيـة المجتمع ـ العربي والإسـلامي ـ بأخطـار العولمـة على كيان الأسرة.

r ـ أن يلتزم أفراد المجتمع ـ العربي والإسلامي ـ بالاستهلاك الرشيد 
حولية كلية الدراسات الإسلامية والعربية بنين بالقاهرة العدد (r r) م ل 1121

r ـ أن تقوم كل دولة بخفض نسبة البطالة بين أبنائها العاملين ،

بتوفير فرص عمل .

ـ ـ يجب القضاء على العوامل التي تؤدي إلى ارتكاب الجريمة. 


\section{ثبت المسادر والمراجع}

1 ـ الإسلام والتحديات الجديدة ، محمد عمارة ، دبي ،ب99 ام.

r ـ الإســلام والحضـارة الغربيـة ، د / محمـد حسين ، ط 9 ، دار

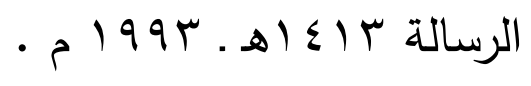

r ـ الإسـلام وحقوق الإنسـان (ضـرورات لا حقوق) محمد عمارة، الكويت ، المجلس الوطنى للثقافة والإعلام والآداب ، مايو 1910

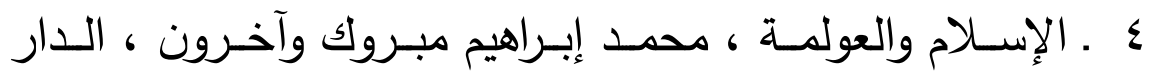

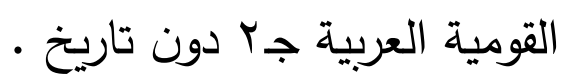
ه ـ التربيـة الإسـلامية وتحديات القرن الحـادى والعشرين ، ضـن

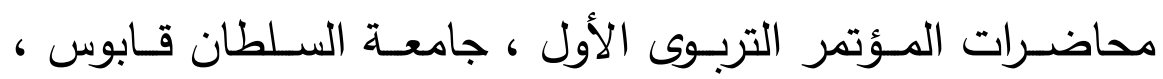

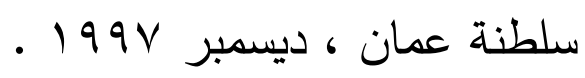

7 ـ ـ التربيـة والعولمـة ، مجدى عزيـز إبـراهيم ، عـالم الكتب سـنـة $\cdot r \cdot r$

V حقوق الإنسـان في الإسـلام ، على عبد الواحد وافى ، دار

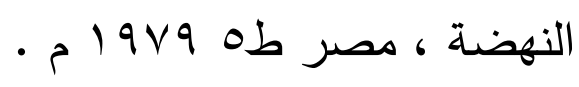

A ـ حقوق الإنسـان في الإسـلام ، عـلام محمد نيـازى ، المؤتمر

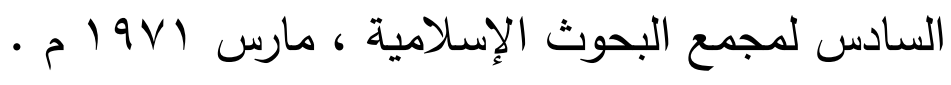


9 ـ الخصــائص العامـة للإســلام ، د / يوسـف القرضـاوى ، دار

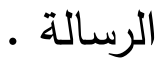

• 1 ـ دور التربية الإسـامية في تنمية الشخصية المصرية لمواجهة اللانظام العالمى اللاجديد ، د / السيد عبد العزيز البهواش ، ضمن أبحاث المؤتمر العاشر لكلية التربية ، جامعة المنصورة ، ديسمبر .1994 1 ا ـ رسالة التوحيد ، محمد عبده ، مطبوعات دار الثعب . r ا ـ صـراع الأمـم بين العولمـة والديمقراطيـة ، أسـعد السـحمرانى ،

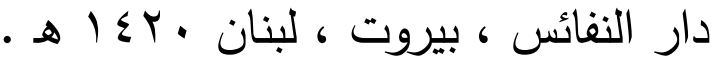
با ـ العولمة أم عالمية الثريعة الإسلامية ، محمد عمر الحاجى ،

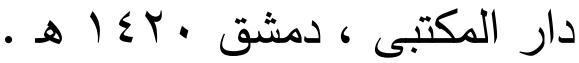
ع ا ـ العولمـة والتعليم الجامعى،المضـامين ، المستقبل - ج ب - م ل ترجمـة السيد عبد العزيز البنهواش ، سـيد بـن حمد الربيعى ،

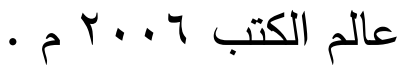
1 ـ العولمة الثقافية وأثرها على الهويـة ، خالد بن عبد الله القاسم ، جامعة الملك سعود ، بحث ع \& أ هـ .

71 ا ـ العولمـة والطريـق الثالـث ، السـيد يسـين ، الهيئـة المصـرية العامة للكتاب ، القاهرة 999 19 م • 
V ا ـ العولمة الغربية والصحوة الإسلامية ، د / عبد الرحمن بن زيد

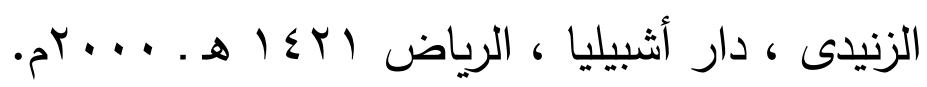

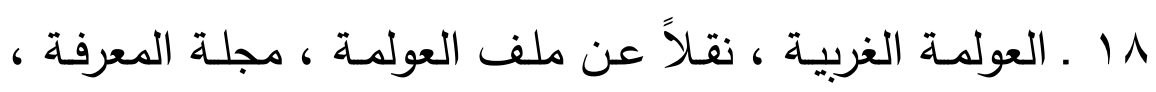

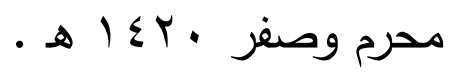

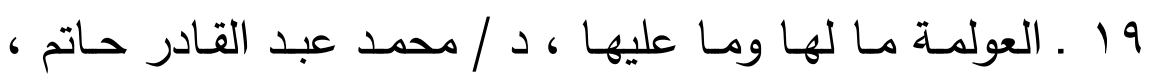

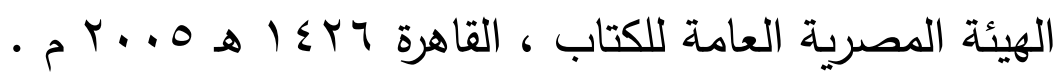

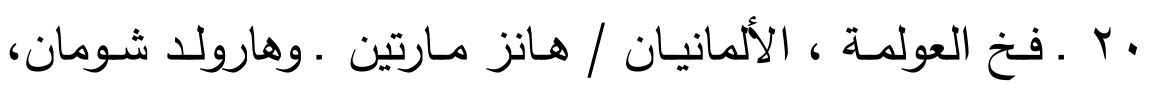

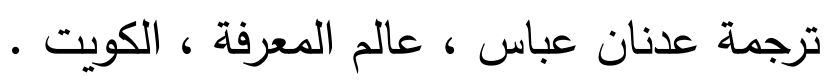

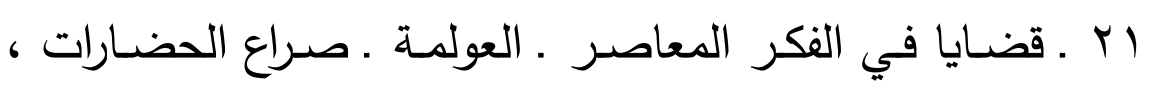

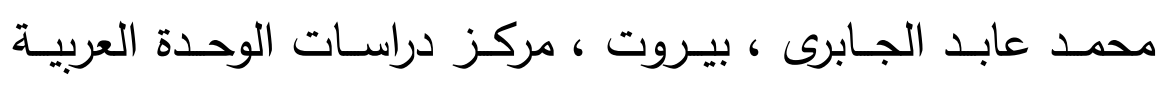
- $199 \mathrm{~V}$

Y Y ـ ـ مخـاطر العولمـة على الهويـة الثقافيـة ، محمد عمـارة ، دار

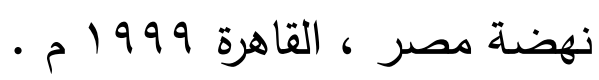

بr ـ ـ موقف الإســلام مـن العولمــة ، د / عبـد الله عبد المحسـن

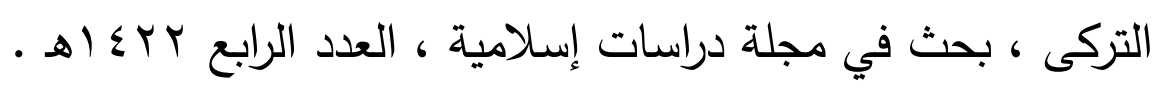


حولية كلية الدراسات الإسلامية والعربية بنين بالقاهرة العدد (r ( )

فهربس الموضومات

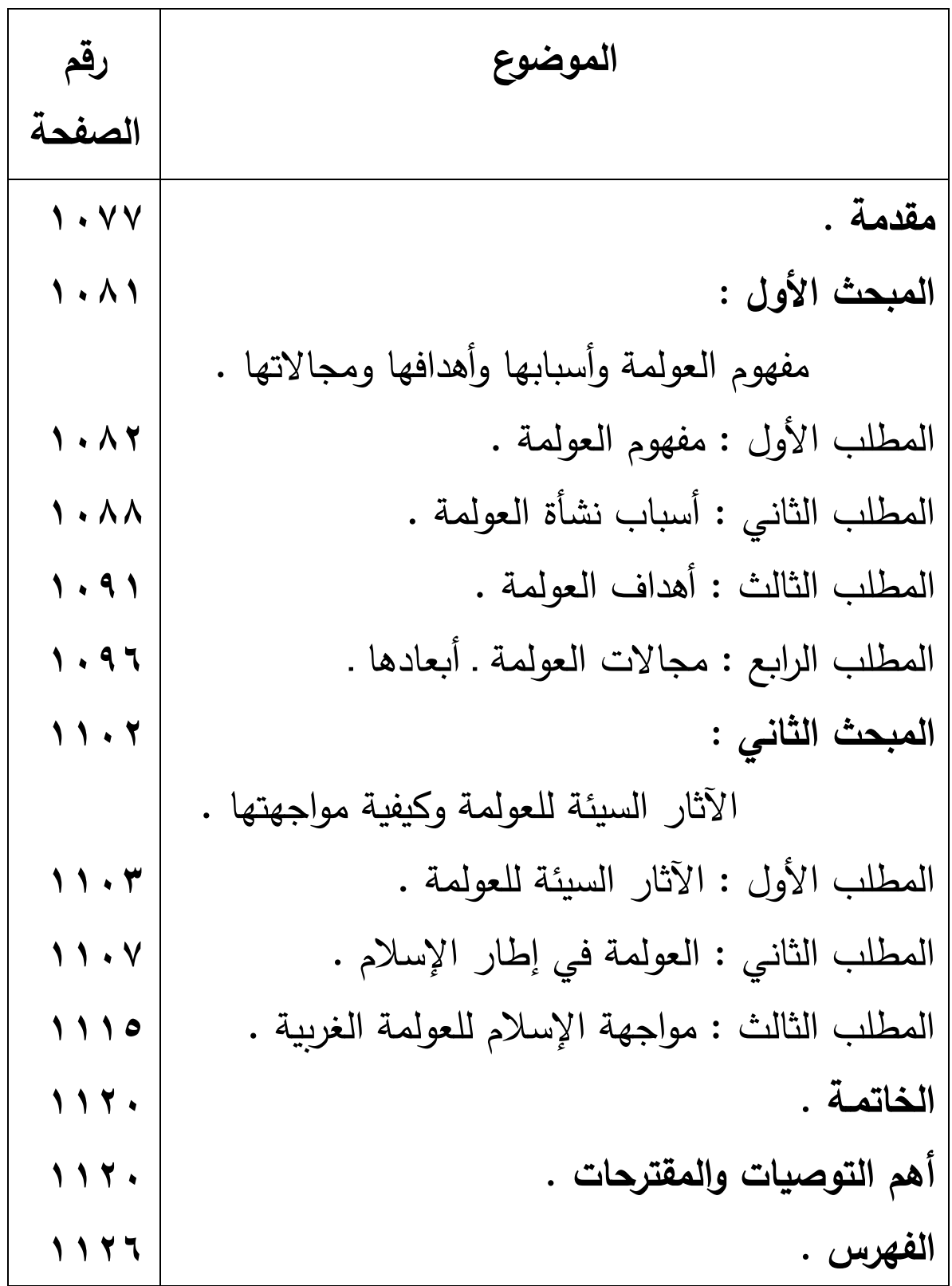

